\title{
Refik TURAN
}

Doç. Dr. | Assoc. Prof. Dr. Aksaray Üniversitesi Eğitim Fakültesi, Türkçe ve Sosyal Bilimler Eğitim Bölümü, Aksaray-TÜRKIYYE Aksaray University, Faculty of Education, Department of Turkish and Social Sciences Education, Aksaray-TURKEY ORCID: 0000-0001-8369-800X refikturan06@gmail.com

\section{Sosyal Bilgiler Dersi Öğretim Programına İlişkin Öğretmen Görüşleri (Aksaray İli Örneği) ${ }^{1}$}

Öz

İlk ve ortaokullarda 2017-2018 öğretim yllından itibaren uygulanmaya başlanan 2017 Sosyal Bilgiler Dersi Öğretim Programını (SBDÖP) öğretmen görüşleri doğrultusunda değerlendirmeyi amaçlayan bu araştırmada genel tarama modeli ile nitel araştırma modelinden oluşan karma model kullanılmıştır. Araştırmanın evrenini Aksaray ili merkez ve ilçelerinde 2018-2019 öğretim y1lında görev yapan 164 sosyal bilgiler öğretmeni, örneklemini ise bu evren içerisinden tesadüfi örneklem yoluyla seçilen 85 sosyal bilgiler öğretmeni oluşturmaktadır. Araştırmada sosyal bilgiler öğretmenlerinin 2017 SBDÖP’nın perspektifi, yaklaşımı, vizyonu ve genel amaçları, beceri eğitimi, değer eğitimi, kavram öğretimi, ölçme ve değerlendirme, öğrenme alanları, ünite ve kazanım, ilişkilendirmeler ve kazanım tablosu boyutlarına ilişkin görüşlerini ortaya koyacak şekilde geliştirilen soru formu ile programın olumlu-güçlü ve eksik-zayıf yönleri ile programa ilişkin değişiklik önerilerini ortaya koyacak şekilde tasarlanmış yarı yapılandırılmış görüşme formu da kullanılmıstır. Araştırma sonucunda Aksaray ilinde görev yapan sosyal bilgiler öğretmenlerinin genel olarak 2017 SBDÖP'na yaklaşımlarının olumlu olduğu, kazanımların azaltılmış olmasını programın en olumlu ve güçlü, kazanımlar için öngörülen sürelerin yetersiz olmasının ise programın en zayıf ve eksik yönü olduğunu düşündükleri sonucuna ulaşılmıştır. Programa ilişkin en sık dile getirilen öneri ise sosyal bilgiler dersine ayrılan haftalık ders saati miktarının artırılması olmuştur. Araştırma sonucunda öğretim programın öğretmenler tarafindan yeterli görülme ve benimsenme oranlarını yükseltilmeye çalışılması, bunun için uygulanma sürecinden elde edilen veriler, konuyla ilgili olarak gerçekleştirilmiş araştırma sonuçları ve öğretmenlerin değişiklik önerilerini dikkate alarak programın güncellenmesinin öğretmenlerin öğretim programının tanıma ve uygulama becerilerinin geliştirilmesine yönelik eğitim faaliyetlerinin düzenlenmesi önerilmiştir

Anahtar Kelimeler: Sosyal Bilgiler, Öğretim Programı, Sosyal Bilgiler Dersi Öğretim Programı, Sosyal Bilgiler Öğretmeni.

\section{Teacher Opinions on 2017 Social Studies Course Curriculum (Example of Aksaray Province)}

\begin{abstract}
In this research, which aims to evaluate the 2017 Social Studies Curriculum; which has been started to be implemented in 2017-2018 academic year in primary and secondary schools, in line with the opinions of teachers, a Mixed Model consisting of a General Screening Model and a Qualitative Research Model was used. The universe of the research consists of 164 social studies teachers working in Aksaray province in 2018-2019 academic year and 85 social studies teachers selected from this universe. In the research, it was developed to reveal the views of the social studies teachers regarding the perspective, approach, vision and general objectives, skill education, value education, concept education, measurement and evaluation, learning areas, unit and achievement, associations and acquisition table dimensions of the 2017 Social Studies Curriculum. The questionnaire and the semi-structured interview form designed to reveal the positive and strong and incomplete and weak aspects of the Program and the proposals for changes related to the program were also used. As a result of the research, it was concluded that the social studies teachers working in Aksaray province generally have positive attitudes towards the 2017 Social Studies Curriculum, and that the achievements have been reduced and that the program is the most positive and strong, and the insufficient time for the achievements is the weakest and the most missing part of the program. As a result of the research, it was proposed to organize training
\end{abstract}

\footnotetext{
1 Aksaray Üniversitesi İnsan Araştımaları Etik Kurulu'nun 19.04.2019 tarih ve 2019/03-46 sayılı kararıyla bu araştırmanın etik ilkelere uygun olduğu onaylanmıştır.
} 
activities aimed at improving the recognition and implementation skills of teachers by updating the program by taking into account the increase in the acceptance and acceptance rates of the curriculum by teachers, the data obtained from the implementation process, the results of the research carried out in relation to the subject, and the suggestions of the teachers' changes.

Keywords: Social Studies, Curriculum, Social Studies Curriculum, Social Studies Teacher.

\section{Giriş}

Öğretim programı bir dersin genel amaçlarını, ders aracılı̆̆ıyla öğrencilere kazandırılması hedeflenen kazanım, beceri, değer, kavram vb. unsurlar ile öğrenme-öğretme sürecine ilişkin önerilerin yer aldığı bir kılavuzdur. Başka bir ifadeyle öğretim programı, "okul ya da okul dışında bireye kazandırılması planlanan bir dersin öğretimiyle ilgili tüm etkinlikleri kapsayan yaşantılar düzeneğidir" (Demirel, 2005: 6). Ülkelerin eğitim sistemlerinin bir parçası olan ve o ülkenin ideolojisini, eğitim felsefesini ve beklentilerini yansıtan öğretim programları katı, değişmez belgeler olmayıp, tam aksine uygulandığı ülkede ve dünyada gerek pedagoji gerekse bilimsel ve teknolojik alanlarda ortaya çıkan gelişmelerin yansıtılması suretiyle güncelliğinin korunması amacıyla belirli aralıklarla güncellenmesi gerekmektedir.

"Toplumsal gerçekle kanıtlanmaya dayalı bağ kurma süreci ve bunun sonucunda elde edilen dirik bilgiler." (Sönmez, 2010: 17) veya "Hemen her bakımdan değişen ülke ve dünya koşullarında bilgiye dayalı karar alıp, problem çözebilen etkin vatandaşlar yetiştirmek amacıyla sosyal ve beşerî bilimlerden aldığı bilgi ve yöntemleri kaynaştırarak kullanan bir öğretim programı" (Öztürk, 2012: 4) olan sosyal bilgiler dersinin temel amac1, demokratik bir ülkede demokratik süreçlerin gelişmesine katk1 sağlayacak etkili vatandaşlar yetiştirmektir (Doğanay, 2002: 17). Söz konusu amaçlanı gerçekleştirebilmek için sosyal bilgiler dersi bireyin gündelik yaşamında etkileşim içerisinde bulunduğu toplumsal hayatın hemen her alanıyla ilgili konuları kapsamaktadır. Günümüzde bilimsel, teknolojik ve pedagojik alanda yaşanan hızlı gelişmeler yine aynı hızda toplumsal hayata da yansımakta; bu da sosyal bilgiler dersinin içeriğinin sürekli olarak güncellenmesini zorunlu kılmaktadır. Türkiye'de ilk defa ayrı bir ders olarak 1968 yılında ilkokullarda okutulmaya başlanan sosyal bilgiler dersi (Bektaş, 2019: 26) 1970-1971 öğretim yllından itibaren üç ylllık denemenin ardından 1973-1974 öğretim yılından başlayarak ortaokullara da yaygınlaştırılmıştır (Turan, 2016: 260). 1985-1986 öğretim yllından itibaren ortaokullarda okutulmakta olan sosyal bilgiler dersi kaldırllarak yerine Millî Tarih, Millî Coğrafya ve Vatandaşlık Bilgisi dersleri okutulmaya başlanmıştır. Bu uygulamaya sekiz yıllık zorunlu temel eğitime geçiş faaliyetleri kapsamında 19981999 öğretim yllından itibaren son verilmiş; bu tarihten itibaren Millî Tarih ve Millî Coğrafya dersleri yerini daha önceden olduğu gibi sosyal bilgiler dersine bırakmıştır (Turan, 2016: 270).

Türkiye'de eğitim sisteminde 2005-2006 öğretim yllından itibaren yapılandırmacılık anlayışının esas alınmaya başlanmasıyla birlikte ilk ve ortaöğretimde okutulan tüm dersler gibi sosyal bilgiler dersi için de yeni anlayışa uygun öğretim programı hazırlanmıştır (Ersoy ve Kaya, 2009: 4). 2005-2006 öğretim y1lında uygulanmaya başlanan bu öğretim programı, süreç içerisinde küçük değiş̧ikliklere uğrasa da 2017 yılına kadar uygulanmıştır. 2017 yllında ilkokul, ortaokul ve liselerde okutulan diğer dersler gibi ilkokul ve ortaokul sosyal bilgiler dersi içinde yeni öğretim programı hazırlanmıştır. Yeni öğretim programı 2017-2018 öğretim yllından itibaren 4. ve 5. sınıflarda, 20182019 öğretim yılından itibaren ise 6. ve 7. sinıflarda uygulanmıştır (Tebliğler Dergisi, 2017: 163; MEB, 2017a; Turan 2018a). MEB, bu program değişikliğinin sosyokültürel hayat, bilim ve teknolojideki hızlı değişim ve gelişmelere bağlı olarak toplumun ve ferdin ihtiyaçlarının değişmesinin yanı sıra MEB'in değişen felsefesinden kaynaklandığını öne sürmüştür (MEB, 2017b: 3). Bu program uygulanmaya başlandıktan yaklaşık dört ay sonra güncellenmiştir (MEB, 2018; Turan, 2018b). 2017 Sosyal Bilgiler Dersi Öğretim Programı (SBDÖP) ile (kendinden önceki programa kıyaslandığında) şu değişikliklerin gerçekleştirildiğini söylemek mümkündür (Çoban ve Akşit, 2018; Taş ve Kıroğlu, 2018; Turan 2018a; Turan, 2018b; Demirci, 2019; Tonga, 2019): 1. 
2017 SBDÖP'da daha önceki programda yer alan dersin genel amaçlarından birisi çıkarılarak ve iki yeni genel amaç eklemek suretiyle dersin genel amaçları on yediden on sekize çıkarılmıştır. 2. 2005 SBDÖP'da on beş beceri sayısı 2017 SBDÖP'da önce yirmi altıya; 2018 güncellemesiyle ise yirmi yediye çıkarılmıştır. 3. Önceki programda kavram öğretimiyle ilgili olarak yer alan temel bilgi ve açıklamalar, sınıflar düzeyinde öğretilecek kavramların listesine 2017 SBDÖP'da yer verilmemiștir. 4. 2005 SBDÖP'da yirmi olan değer sayıs1 2017 SBDÖP'da on sekize indirilmiştir. 5. 2017 SBDÖP'da daha önceki programda yer alan "Güç, Yönetim ve Toplum”, "Gruplar, Kurumlar ve Sosyal Örgütler" ve "Zaman, Süreklilik ve Değişim” öğrenme alanları programdan çıkarılmış, buna karşlık "Etkin Vatandaşlık" isimli yeni bir öğrenme alanı oluşturulmuştur. 6. 2017 SBDÖP'da ünite yapılandırmasına gidilmemiştir. 7. 2005 SBDÖP'da 175 olan kazanım sayısı 2017 SBDÖP'da önce 134'e, 2018 güncellemesiyle ise 130'a indirilmiştir. 8. 2005 SBDÖP'da göz önünde tutulan ilişkilendirmelere 2017 SBDÖP'da yer verilmemiştir. 9. 2017 SBDÖP'da ölçme ve değerlendirme ve rehberlik gibi konularla ilgili daha kısa ve derse özgü olmayan genel nitelikli bilgilere yer verilmiştir. 10. 2017 SBDÖP'da kazanım tablosu sadeleştirilmiş, önceki programda kazanım tablosu üzerinde gösterilen kavram, ilişkilendirme, yöntem ve teknik, ölçme ve değerlendirme, etkinlik vb. önerilere yer verilmemiştir.

\subsection{Araştırmanın Amac1}

Bu araştırmanın amacı sosyal bilgiler öğretmenlerinin 2017-2018 öğretim yılından itibaren uygulanmaya başlanan 2017 SBDÖP’na ilişkin görüşlerini ortaya koymaktır. Bu amaca yönelik olarak aşağıdaki sorulara yanıt aranmıştır:

1. Sosyal bilgiler öğretmenlerinin 2017 SBDÖP'nın perspektifi, yaklaşımı, vizyonu ve genel amaçlarına yönelik görüşleri nelerdir?

2. Sosyal bilgiler öğretmenlerinin 2017 SBDÖP’nın beceri eğitimi boyutuna ilişkin görüşleri nelerdir? nelerdir?

3. Sosyal bilgiler öğretmenlerinin 2017 SBDÖP'nın değer eğitimi boyutuna ilişkin görüşleri

4. Sosyal bilgiler öğretmenlerinin 2017 SBDÖP’nın kavram öğretimi boyutuna ilişkin görüşleri nelerdir?

5. Sosyal bilgiler öğretmenlerinin 2017 SBDÖP'nın ölçme ve değerlendirme boyutuna ilişkin görüşleri nelerdir?

6. Sosyal bilgiler öğretmenlerinin 2017 SBDÖP’nın öğrenme alanları, ünite ve kazanım boyutlarına ilişkin görüssleri nelerdir?

7. Sosyal bilgiler öğretmenlerinin 2017 SBDÖP’nın ilişkilendirmeler boyutuna ilişkin görüşleri nelerdir? nelerdir?

8. Sosyal bilgiler öğretmenlerinin 2017 SBDÖP’nın kazanım tablosuna ilişkin görüşleri

9. Sosyal bilgiler öğretmenlerine göre 2017 SBDÖP’nın olumlu ve güçlü yönleri nelerdir?

10. Sosyal bilgiler öğretmenlerine göre 2017 SBDÖP'nın eksik ve zayıf yönleri nelerdir?

11. Sosyal bilgiler öğretmenlerinin 2017 SBDÖP'da gerçekleştirilmesini istedikleri değişiklikler nelerdir?

\subsection{Araştırmanın Önemi}

Alanyazında 2017-2018 öğretim y1lından itibaren uygulanmaya başlanan 2017 SBDÖP'nı farklı boyutlarıyla ele alıp inceleyen birçok çalışmanın gerçekleştirildiği, ancak öğretim programını öğretmen görüşleri doğrultusunda farklı boyutlarıyla bir bütün olarak ele alıp değerlendiren çalışmaların yok denecek kadar az olduğu anlaşılmaktadır. 2017 SBDÖP’nı bir bütün olarak 
öğretmen görüşleri doğrultusunda tanılamayı amaçlayan bu araştırmanın alanındaki önemli bir boşluğu dolduracağı ve araştırmada elde edilen bulgular ve varılan sonuçların programın eksikliklerini gidermeye yönelik güncelleme çalışmalarına $1 s ̧ 1 \mathrm{k}$ tutacak önemli veriler sunacağ1 düşünülmektedir.

\section{Yöntem}

\subsection{Araştırmanın Modeli}

Araştırmada farklı yöntemlerin bir arada kullanılmasına olanak tanıyan Karma Model (Mixed Type) kullanılmıştır. Karma araştırma; tek bir çalışmanın ya da çalışmalar içerisindeki nitel ve nicel araştırma verilerinin toplanmasını, analiz edilmesini ve yorumlanmasını içerir (Leech ve Onwuegbuzie, 2009: 266). Bu araştırmada da Tarama Modeli ve Nitel Araştırma Modeli bir arada kullanılarak her iki modelin avantajlarından yararlanılmaya çalışılmıştır. Araştırmanın nicel boyutunu oluşturan Tarama Modelinde "var olan bir durumun olduğu hâliyle tespit edilmesi ve ortaya konulması hedeflenir" (Karasar, 1998: 208). "Gözlem, görüşme ve doküman analizi gibi nitel veri toplama tekniklerinin kullanıldığı; algıların ve olayların doğal ortamda gerçekçi ve bütüncül bir biçimde ortaya konmasına yönelik nitel bir sürecin izlendiği” (Yıldırım ve Şimşek, 2003: 391) şeklinde tanımlanabilen Nitel Araştırma Modeli ise araştırmacıya sorunları, içinde doğup geliştiği değerler sistemi, yani kendi bağlamı içerisinde ele alıp, yorumlama ve anlamlandırma olanağı sunar (Neuman, 2012: 224).

\subsection{Araştırmanın Çalışma Grubu}

Araştırmanın evrenini Aksaray ili merkez ve ilçelerinde 2018-2019 öğretim yllında görev yapan 164 sosyal bilgiler öğretmeni, örneklemini ise bu evren içerisinden Oransız Eleman Örnekleme (Basit Tesadüfi Örnekleme) yoluyla seçilen 85 sosyal bilgiler öğretmeni oluşturmaktadır. Oransız Eleman Örnekleme, evrendeki tüm elemanların birbirlerine eşit seçilme şansına sahip oldukları, evrendeki eleman türlerinden örnekleme girenlerin sayısının tümü ile şansa bırakıldığı bir örnekleme türüdür (Karasar, 1998: 113). Örnekleme dâhil olan sosyal bilgiler öğretmenlerinden 2017 SBDÖP'nı farklı boyutlarıyla değerlendirmelerine olanak sağlayacak şekilde hazırlanan soru formu ve yarı yapılandırılmış görüşme formunu doldurmaları istenmiştir.

Aşağıda çalışma grubunun cinsiyet, yaş, mezun oldukları bölüm ve mesleki kıdem durumlarıla ilgili bilgilere yer verilmiştir.

Tablo 1. Araştırma Grubunun Cinsiyet Özellikleri

\begin{tabular}{lcc}
\hline Cinsiyet & Say1 & Oran \\
\hline Kadin & 41 & 48,2 \\
Erkek & 44 & 51,8 \\
\hline TOPLAM & 85 & 100 \\
\hline
\end{tabular}

Araştırmaya katılan sosyal bilgiler öğretmenlerinin $41^{\prime} \mathrm{i}(\% 48,2), 44^{\prime} \ddot{\mathrm{u}}(\% 51,8)$ ise erkek öğretmenlerden oluşmaktadır.

Tablo 2. Araştırma Grubunun Yaş Özellikleri

\begin{tabular}{lccc}
\hline & Hizmet Y11 & Say1 & Oran \\
\hline $\mathbf{2 0 - 3 0}$ & 15 & 17,6 \\
$\mathbf{3 1 - 4 0}$ & 37 & 43,5 \\
$\mathbf{4 1 - 5 0}$ & 28 & 33,0 \\
$\mathbf{5 1 - 6 0}$ & 5 & 5,9 \\
\hline TOPLAM & 85 & 100 \\
\hline
\end{tabular}

Araştırmaya katılan sosyal bilgiler öğretmenlerinin 15’inin (\%17,6) 20-30, 37'sinin (\%43,5) 31-40, 28 'inin (\%33) 41-50, 5'inin (\%5,9) ise 51-60 yaş aralığında oldukları anlaşılmaktadır.

Tablo 3. Araştırma Grubunun Mezun Oldukları Bölüm

\begin{tabular}{lcl}
\hline Mezun Olunan Bölüm & Sayı & Oran \\
\hline Sosyal Bilgiler Öğretmenliği Lisans Mezunu & 44 & 51,8 \\
Diğger & 41 & 48,2 \\
\hline
\end{tabular}


TURAN, Refik (2020). “2017 Sosyal Bilgiler Dersi Öğretim Programına İlişkin Öğretmen Görüşleri (Aksaray İli Örneği)", Mavi Atlas, 8(2): 256-277

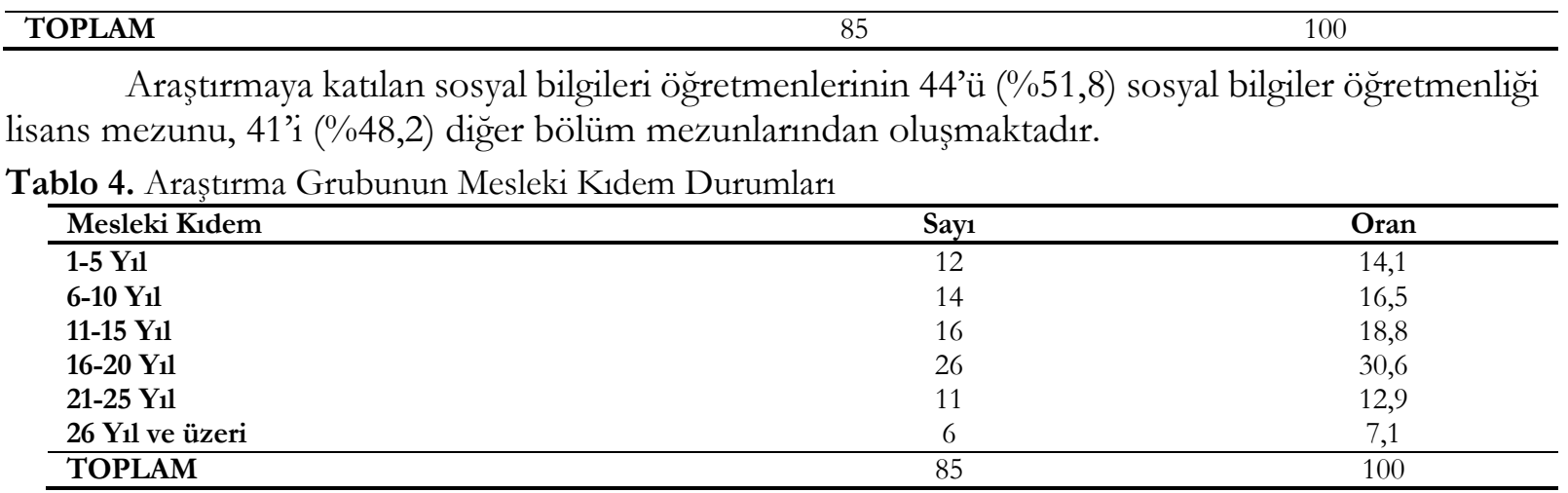

Tablo 4.'de görüldüğü gibi araştırmaya katılan sosyal bilgiler öğretmenlerinin 12'si (\%14,1) 1-5, 14’ü (\%16,5) 6-10, 16’s1 (\%18,8) 11-15, 26’s1 (\%30,6) 16-20, 11’i (\%12,9) 21-25 y1l arasinda, 6 's1 ise $(\% 7,1) 26$ yıl ve üzeri mesleki kıdeme sahiptirler.

\subsection{Veri Toplama Araçları ve Süreci}

Araştırmanın nicel boyutunda verilerin toplanmasında araştırmacı tarafindan ilgili alanyazından da yararlanılarak (Taş ve Kıroğlu, 2018; İnce ve Yavuz, 2018; Demirci, 2019) da yararlanılarak geliştirilen ve 2017 SBDÖP'nın temel unsurlarını ve özelliklerini sosyal bilgiler öğretmenlerinin gözünden değerlendirilmesine olanak tanıyan önermelerin yer aldığ1 soru formu kullanılmıştır. Soru formunda sosyal bilgiler öğretmenlerinin 2017 SBDÖP’nı farklı boyutlarıyla değerlendirmelerine olanak sağlayacak şekilde hazırlanan elli iki adet kapalı uçlu "beşli-Likert tipi soru"ya yer verilmiştir.

Araştırmanın nitel boyutunda ise yine araştırmacı tarafından geliştirilen, araştırmaya katılanların 2017 SBDÖP’nın olumlu ve güçlü, eksik ve zayıf yönleri ile programa ilişkin değişiklik önerilerini ortaya koymaya yönelik açık uçlu üç sorunun yer aldığ1 yarı yapılandırılmış görüşme formu kullanılmıştır. Araştırmaya katılan sosyal bilgiler öğretmenlerinden yarı yapılandırılmış görüşme formunda yer alan "bana göre 2017 SBDÖP’nın olumlu ve güçlü yönleri şunlardır:", "bana göre 2017 SBDÖP’nın eksik ve zayıf yönleri şunlardır:” ve "2017 SBDÖP’da şu değişikliklerin gerçekleştirilmesi uygun olur:” şeklindeki başlıkların altına düşüncelerini belirtmeleri istenmiştir.

Soru formunda ve yarı yapılandırılmış görüşme formunda yer alan soruların uygunluğu alan eğitimcisi ve eğitim bilimleri uzmanı tarafindan kontrol edilmiş; ayrıca soruların yeterince açık ve anlaş1ır olup olmadığı ve cevaplama süresinin uygunluğu çalışma grubuna dâhil olmayan on kişilik başka bir gruba uygulanmak suretiyle test edilmiştir. Alınan dönütler doğrultusunda soru formu ve yarı yapılandırılmış görüşme formuna son şekli verildikten sonra 2019 yılının Mayıs-Kasım aylarında çalışma grubuna uygulanmıştır.

\subsection{Verilerin Analizi}

Araştırmanın kapalı uçlu sorulardan oluşan nicel boyutunda elde edilen veriler SPSS programı kullanılarak analiz edilmiş; öğretmen yanıtlarının frekans ve yüzdeleri hesaplanmış ve ilgili kategoriler altında tablolaştırılmıştır.

Araştırmanın nitel boyutunu oluşturan yarı yapılandırılmış görüşme formunda yer alan açık uçlu sorulara verilen öğretmen yanıtları içerik analizine tabi tutulmuştur. "İçerik analizinde temelde yapılan işlem, birbirine benzeyen verileri belirli kavramlar ve temalar çerçevesinde bir araya getirmek ve bunları okuyucunun anlayabileceği bir biçimde organize edilerek yorumlamaktır (Yıldırım ve Şimşek, 2003: 162). Bu çalışmada da yarı yapılandırılmış görüşme formunu dolduran 52 sosyal bilgiler öğretmeninin verdikleri yanıtlardan aynı anlama sahip olanlar bir araya getirilmek suretiyle frekansları hesaplanmış ve her üç kategorideki en yüksek frekansa sahip beş yanıt tablo hâlinde gösterilmiştir. 
TURAN, Refik (2020). “2017 Sosyal Bilgiler Dersi Öğretim Programına İlişkin Öğretmen Görüşleri (Aksaray İli Örneği)", Mavi Atlas, 8(2): 256-277

Son olarak araştırmanın nicel ve nitel boyutlarına ilişkin öğretmen görüşlerini frekans ve yüzde olarak gösteren tablolara ilgili kategoriler altında yer verilmiş ve yorumlanmıştır.

\subsection{Araştırmanın Etik İzinleri}

Yapılan bu çalışmada "Yükseköğretim Kurumları Bilimsel Araştırma ve Yayın Etiği Yönergesi" kapsamında uyulması belirtilen tüm kurallara uyulmuştur. Yönergenin ikinci bölümü olan "Bilimsel Araştırma ve Yayın Etiğine Aykırı Eylemler" başlı̆̆1 altında belirtilen eylemlerden hiçbiri gerçekleştirilmemiştir. Kurulu

Araştırmanın etik kurul onayını veren kurum: Aksaray Üniversitesi İnsan Araştırmaları Etik

Etik kurul onay tarihi:19.04.2019

Etik kurul onay sayısı:2019/03-46

\section{Bulgular}

Araştırmanın bu bölümünde araştırmanın amacına yönelik olarak geliştirilerek uygulanan nitel ve nicel veri toplama araçlarından elde edilen verilerin analizinden elde edilen bulgulara yer verilmiştir. Elde edilen bulgular, ilgili kategoriler altında ele alınarak değerlendirilmiştir.

\subsection{SBDÖP’nın Vizyonu, Perspektifi, Yaklaşımı ve Genel Amaçlarına İlişkin Öğretmen Görüşleri}

2017 SBDÖP'nın vizyonu, yaklaşımı, perspektifi ve genel amaçlarına ilişkin öğretmen görüşlerinin ortaya konulmaya çalışıldığı araştırmanın bu kategorisinde araştırmaya katılan sosyal bilgiler öğretmenlerinin verdiği yanıtlar aşağıda tablo hâlinde (Tablo 5) gösterilmiştir.

Tablo 5. 2017 SBDÖP’nın Vizyonu, Perspektifi, Yaklaşımı Genel Amaçlarına ilişkin Öğretmen Görüşleri

\begin{tabular}{|c|c|c|c|c|c|c|c|}
\hline & & & 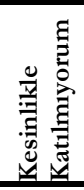 & 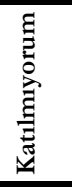 & 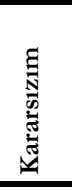 & 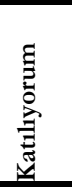 & 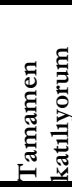 \\
\hline \multirow[t]{2}{*}{1} & 2017 SBDÖP’nın vizyonu/perspektifi, genel yaklaşımı açık ve nettir. & $F$ & 6 & 9 & 11 & 51 & 8 \\
\hline & & $\%$ & 7,1 & 10,6 & 12,9 & 60,0 & 9,4 \\
\hline \multirow[t]{2}{*}{2} & 2017 SBDÖP bireyin bilişsel, duyuşsal ve devinişsel yönden bir bütün olarak & $F$ & 3 & 17 & 13 & 44 & 8 \\
\hline & gelişimini sağlayacak şekilde hazırlanmıstır. & $\%$ & 3,5 & 20,0 & 15,3 & 51,8 & 9,4 \\
\hline \multirow[t]{2}{*}{3} & 2017 SBDÖP’nda bilgi-beceri-değer dengesi yeterli düzeyde kurulmuştur. & $F$ & 4 & 21 & 16 & 36 & 8 \\
\hline & & $\%$ & 4,7 & 24,7 & 18,8 & 42,4 & 9,4 \\
\hline \multirow[t]{2}{*}{$\overline{4}$} & 2017 SBDÖP'nda $\quad$ yerellik-ulusallık-evrensellik $\quad$ dengesi $\quad$ yeterli & $F$ & 3 & 22 & 10 & 40 & 10 \\
\hline & kurulmuştur. & $\%$ & 3,5 & 25,9 & 11,8 & 47,0 & 11,8 \\
\hline \multirow[t]{2}{*}{5} & 2017 SBDÖP yapılandırmacı yaklaşımın temel ilkeleriyle uyumludur. & $F$ & 4 & 13 & 11 & 38 & 19 \\
\hline & & $\%$ & 4,7 & 15,3 & 12,9 & 44,7 & 22,4 \\
\hline \multirow[t]{2}{*}{$\overline{6}$} & 2017 SBDÖP öğrenci merkezli bir eğitime yöneltmektedir. & $F$ & 3 & 14 & 14 & 40 & 14 \\
\hline & & $\%$ & 3,5 & 16,5 & 16,5 & 47,0 & 16,5 \\
\hline \multirow[t]{2}{*}{7} & 2017 SBDÖP'da yer alan dersin genel amaçları Türk Millî Eğitiminin genel ve özel & $F$ & 5 & 5 & 14 & 46 & 15 \\
\hline & amaçlarıyla uyumludur. & $\%$ & 5,9 & 5,9 & 16,5 & 54,1 & 17,6 \\
\hline \multirow[t]{2}{*}{$\overline{8}$} & 2017 SBDÖP'nın genel amaçları çağın genel yönelimlerine uygun olarak & $F$ & 5 & 18 & 10 & 42 & 10 \\
\hline & 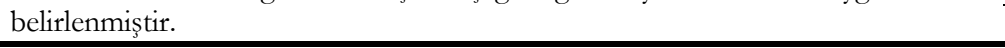 & $\%$ & 5,9 & 21,1 & 11,8 & 49,4 & 11,8 \\
\hline \multirow[t]{2}{*}{$\overline{9}$} & 2017 SBDÖP'nın genel amaçları açık ve anlaşılır olarak ifade edilmiştir. & $F$ & 4 & 14 & 8 & 45 & 14 \\
\hline & & $\%$ & 4,7 & 16,5 & 9,4 & 52,9 & 16,5 \\
\hline \multirow[t]{2}{*}{10} & 2017 SBDÖP’da yer alan dersin genel amaçlarına mevcut programla ulaşılabilir. & $F$ & 6 & 6 & 21 & 40 & 12 \\
\hline & & $\%$ & 7,1 & 7,1 & 24,7 & 47,0 & 14,1 \\
\hline \multirow[t]{2}{*}{$\overline{11}$} & 2017 SBDÖP'da yer alan "programın uygulanmasında dikkat edilecek hususlar" & $F$ & 5 & 13 & 18 & 45 & 4 \\
\hline & başlığı altında verilen açıklamalar yeterlidir. & $\%$ & 5,9 & 15,3 & 21,2 & 52,9 & 4,7 \\
\hline \multirow[t]{2}{*}{12} & 2017 SBDÖP esnek olup, öğretmene şartlara göre uyarlama imkânı sunmaktadır. & $F$ & 3 & 11 & 11 & 42 & 18 \\
\hline & & $\%$ & 3,5 & 12,9 & 12,9 & 49,5 & 21,2 \\
\hline 13 & & $F$ & 5 & 21 & 20 & 28 & 11 \\
\hline
\end{tabular}




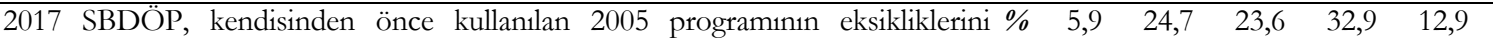
gidermiştir.

Tablo 5’de de görüldüğü gibi “2017 SBDÖP'nın vizyonu, perspektifi, genel yaklaşımı açık ve nettir." șeklindeki önermeye "katılıyorum" ve "kesinlikle katılıyorum" yanıtını verenlerin toplam oran1 \%69,4 iken; "kararsızım" yanıtını verenlerin oranı \%12,9, "katılmıyorum" ve "kesinlikle katılmıyorum" yanıtını verenlerin toplam oranı \%17,7’dir. Bu yanıtlar katılımcıların yaklaşık \% 70 'lik bölümünün yeni programın vizyonu, perspektifi ve genel yaklaşımının yeterince açık ve net olduğunu düşündüklerini ortaya koymaktadır. "2017 SBDÖP bireyin bilişsel, duyuşsal ve devinişsel yönden bir bütün olarak gelişimini sağlayacak şekilde hazırlanmıştır.” önermesine araştırmaya katılanların \%61,2'si "katılıyorum" ve "tamamen katıliyorum" yanıtını verirken; "karasızım" yanıtını verenlerin oran $\% 15,3$, "katılmıyorum" yanıtını verenlerin oranı $\% 20,0$, "kesinlikle katılmiyorum" yanıtını verenlerin oranı ise \% 3,5'tir. Araştırmaya katılan öğretmenlerin yaklaşık \%40’lık bölümünün kararsız olduklarını ya da katılmadıklarını belirtmeleri program açısından önemli bir çekince olarak görülmelidir. "2017 SBDÖP’nda bilgi-beceri-değer dengesi yeterli düzeyde kurulmuştur." önermesine "katıliyorum" ve "tamamen katıliyorum" yanıtını verenlerin toplam oran1 \%51,8'dir. Bu konuda "kararsı" olduğunu belirtenlerin oran1 \%18,8 ile bu kategorinin en yüksek oranlarındandır. "Katılmıyorum" ve "kesinlikle katılmıyorum" yanıtını verenlerin toplam oran1 ise \%29,4 ile bu kategorideki en yüksek orandır. "2017 SBDÖP'nda yerellik-ulusallıkevrensellik dengesi yeterli düzeyde kurulmuştur." önermesine "katıllyorum" ve "tamamen katıliyorum" yanıtını verenlerin toplam oran $1 \% 58,8$, "kararsızım" yanitını verenlerin oran $1 \% 11,8$, "katılmıorum" ve "kesinlikle katılmıyorum" yanıtını verenlerin toplam oranının ise \%29,4 olduğu anlaşılmaktadır. Bu yanıtlar öğretmenlerin önemli bir bölümünün 2017 SBDÖP'nda yerellikulusallık-evrensellik dengesinin yeterli düzeyde kurulmadığını düșündüklerini göstermektedir. “2017 SBDÖP yapılandırmacı yaklaşımın temel ilkeleriyle uyumludur." önermesine "katıllıorum" ve "tamamen katiliyorum" yanitın verenlerin toplam oran $1 \% 67,1$, "kararsızım" yanitını verenlerin oranı \%12,9, "katılmiyorum" ve "kesinlikle katılmiyorum" yanıtını verenlerin toplam oranı ise \%20'dir. Bu yanıtlar araştırmaya katılan sosyal bilgiler öğretmenlerinin önemli bir bölümünün öğretim programının yapılandırmacı yaklaşımın temel ilkelerini yansıttı̆̆ını düşündüğünü ortaya koymaktadır. Ayrıca bu önermeye "tamamen katıliyorum" yanıtını verenlerin oran1 $(\% 22,4)$ bu kategorinin en yüksek oranıdır. Bu önermeyle yakından ilgili olan "2017 SBDÖP öğrenci merkezli bir eğitime yöneltmektedir." önermesine "katıllyorum" ve "tamamen katıllyorum" yanıtını verenlerin toplam oran1 \%63,5, "kararsızım" yanıtını verenlerin oran1 \%16,5, "katılmiyorum" ve "kesinlikle katılmıyorum" yanıtını verenlerin toplam oranı ise \%20'dir. Bu yanıtlar "programın yapılandırmacı yaklaşımın temel ilkelerine uygunluğu" ile ilgili bir önceki önermeye verilen yanıtlarla uyumluluk göstermektedir. "2017 SBDÖP'da yer alan dersin genel amaçları Türk Millî Eğitiminin genel ve özel amaçlarıyla uyumludur." önermesine "katılıyorum" ve "tamamen katılıyorum" yanıtını verenlerin toplam oranı $(\% 71,7)$ bu kategorideki en yüksek orandır. Bu önermeye "katılmıorum" ve "kesinlikle katılmıyorum" yanıtını verenlerin toplam oranı \%11,8 iken, "kararsızım" yanıtını verenlerin oranı \%16,5'tir. "SBDÖP'nın genel amaçları çağın genel yönelimlerine uygun olarak belirlenmiştir." önermesine "katılıyorum" ve "kesinlikle katılıyorum" yanıtlarını verenlerin toplam oran1 \%61,2, "kararsızım" yanıtını verenlerin oran1 \%11,8, "katılmiyorum" ve "kesinlikle katılmıorum" yanıtlarını verenlerin toplam oranı ise \%27'dir. "2017 SBDÖP'nın genel amaçları açık ve anlaşılır olarak ifade edilmiştir." şeklindeki önermeye "katıllıorum" ve "tamamen katılıyorum" yanıtını verenlerin toplam oranı $\% 68,4$ olup bu kategorinin en yüksek ikinci oranıdır. $\mathrm{Bu}$ önermeye "kararsızım" yanitını verenlerin oranı \%9,4, "katılmıyorum" ve "kesinlikle katılmiyorum" yanıtını verenlerin toplam oranı ise \%21,2'dir. "2017 SBDÖP'da yer alan dersin genel amaçlarına mevcut programla ulaşılabilir." önermesine "katıliyorum" ve "tamamen katılıyorum" yanıtını verenlerin toplam oran1 \%61,1, "kararsızım" yanıtını verenler ise \% 24,7 'lik bir oran ile bu kategorideki en yüksek düzeydir. Bu önermeye "katılmıyorum" yanıtını verenlerin oranı 
\%7,1'lik oran ile bu kategorideki en düşük ikinci oran iken, "kesinlikle katılmıyorum" yanıtını verenlerin oranı da \%7,1'dir. "2017 SBDÖP'nda yer alan "programın uygulanmasında dikkat edilecek hususlar' başlığı altında verilen açıklamalar yeterlidir." şeklindeki önermeye "katıllıorum" yanıtını verenlerin oranı \%52,9 iken "tamamen katlliyorum" yanıtını verenlerin oranı \% $\%, 7$ 'lik bir oranla bu kategorinin en düşük oranıdır. Bu önermeye "kararsızım" yanıtını verenlerin oranı \%21,2, "katılmıyorum" ve "kesinlikle katılmıyorum" yanıtını verenlerin toplam oranı ise \%21,2'dir. "2017 SBDÖP esnek olup, öğretmene şartlara göre uyarlama imkânı sunmaktadır." önermesine "katilıyorum" yanıtını verenlerin oranı \%49,5, "tamamen katıliyorum" yanıtını verenlerin oranı \%21,2, "katılmıyorum" ve "kararsızım" yanıtını verenlerin oranı \%12,9, "kesinlikle katılmiyorum" yanıtını verenlerin oranı ise \%3,5'tir. "2017 SBDÖP kendisinden önce kullanılan 2005 programının eksikliklerini gidermiştir." önermesine "katıliyorum" yanıtını verenlerin oranı \%32,9 olup, bu kategorideki en düşük orandır. Öyle ki bu kategorideki ikinci en düşük "katılıyorum" oranı $\% 42,4$ olup aradaki fark \%10'dan daha fazladır. "Katıliyorum" ve "tamamen katıliyorum" oranlarının toplamı $\% 45,8$ olup yine bu kategorinin en düşük oranıdır. Bu önermeyle ilgili "kararsızım” yanıtını verenlerin oranı $\% 23,6$ 'lık bir oran ile bu kategorinin en yüksek oranı iken "katılmıyorum" yanıtı da \%24,7'lik oranla bu kategorideki en yüksek ikinci orandır. Bu önermeye "kesinlikle katılmıyorum" yanıtını verenlerin oranı ise \%5,9'dur. Dolayısıyla bu sonuçlar katılımcıların 2017 SBDÖP’nda 2005 SBDÖP’nda var olan eksikliklerin giderilmediğini düşündüklerini ortaya koymaktadır.

\subsection{SBDÖP’nın Beceriler Boyutuna İlişkin Öğretmen Görüşleri}

Araştırmanın 2017 SBDÖP'nı öğretmen görüşleri doğrultusunda beceri boyutuyla değerlendirmeyi amaçlayan bu kategorisinde araştırmaya katılan sosyal bilgiler öğretmenlerinin verdikleri yanıtlar aşağıdaki tabloda (Tablo 6 ) gösterilmiştir.

Tablo 6. 2017 SBDÖP’nın Beceriler Boyutuna İlişkin Öğretmen Görüşleri

\begin{tabular}{|c|c|c|c|c|c|c|c|}
\hline & & & 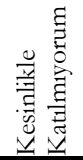 & 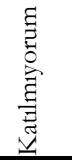 & 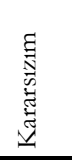 &  & 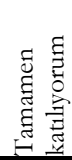 \\
\hline \multirow[t]{2}{*}{$\overline{1}$} & \multirow{2}{*}{$\begin{array}{l}2017 \text { SBDÖP'nda beceriler ile ilgili yer verilen teorik bilgi ve açılamalar } \\
\text { yeterlidir. }\end{array}$} & $f$ & 6 & 20 & 13 & 39 & 7 \\
\hline & & $\%$ & 7,1 & 23,5 & 15,3 & 45,9 & 8,2 \\
\hline \multirow[t]{2}{*}{2} & & $f$ & 4 & 14 & 15 & 43 & 9 \\
\hline & 2017 SBDÖP'nda yer verilen beceriler sayıca yeterlidir. & $\%$ & 4,7 & 23,5 & 17,6 & 50,6 & 10,6 \\
\hline \multirow[t]{2}{*}{3} & 2017 SBDÖP öngörülen becerileri ögrencilere kazandırmaya imkân verecek & $f$ & 8 & 14 & 17 & 37 & 9 \\
\hline & șekilde hazırlanmıştır. & $\%$ & 9,4 & 16,5 & 20,0 & 43,5 & 10,6 \\
\hline \multirow[t]{2}{*}{$\overline{4}$} & & $f$ & 1 & 22 & 20 & 29 & 13 \\
\hline & 2017 SBDÖP üst düzey düşünme becerileri kazandırmaya uygundur. & $\%$ & 1,2 & 25,9 & 23,5 & 34,1 & 15.3 \\
\hline \multirow[t]{2}{*}{5} & & $f$ & 6 & 9 & 13 & 43 & 14 \\
\hline & 2017 SBDÖP beceri eğitimi açısından 2005 SBDÖP’nın daha da ilerisindedir. & $\%$ & 7,0 & 10,6 & 15,3 & 50,6 & 16,5 \\
\hline
\end{tabular}

Tablo 6'da da görüldüğü gibi araştırmaya katılan sosyal bilgiler öğretmenlerinin 2017 SBDÖP”nın beceri boyutuna ilişkin yanıtları şöyledir: “2017 SBDÖP'nda beceriler ile ilgili yer verilen teorik bilgi ve açıklamalar yeterlidir." şeklindeki önermeye "katıllyorum" yanıtını verenlerin $\% 45,9$, “tamamen katıliyorum” yanıtını verenlerin \%8,2'lik orana sahip olduğu görülmektedir. Bu önermeye "tamamen katılıyorum" yanıtını verenlerin oranı bu kategorideki en düşük oran iken, "katılmıorum" yanıtını verenlerin oranı $(\% 23,5)$ bu kategorideki en yüksek oranlardan biridir. Yine bu önermeye "kararsızım" yanıtını verenlerin oranı \%15,3, "kesinlikle katılmıyorum" yanıtını verenlerin oranı ise \%7,1'dir. "2017 SBDÖP'nda yer verilen beceriler sayıa yeterlidir." şeklindeki önermeye "katıliyorum" ve "tamamen kat1lyorum" yanıtını verenlerin toplam oranı \%61,2 iken; "kararsızım" yanıtını verenlerin oranı \%17,6, "katılmıyorum" yanıtını verenlerin oran1 \%16,5, "kesinlikle katılmıyorum" yanıtını verenlerin oranı ise \%4,7'dir. Bu önermeye "katıliyorum" yanıt1 verenlerin oranı $(\% 50,6)$ bu kategorideki en yüksek orandır. "2017 SBDÖP, öngörülen becerileri 
öğrencilere kazandırmaya imkân verecek şekilde hazırlanmıştır." önermesine "katıllyorum" yanıtını verenler \%43,5, "tamamen katılıyorum" yanıtını verenler \%10,6, "kararsızım" yanıtını verenler $\% 20,0$, "katilmiyorum" yanitını verenler \%16,5, "kesinlikle katılmiyorum" yanitını verenler ise $\% 9,4$ 'lük bir orana sahiptir. Bu önermeye "katıllyorum" yanıtını verenlerin oranı $(\% 43,5)$ bu kategorideki en düşük ikinci orandır. "2017 SBDÖP üst düzey düşünme becerileri kazandırmaya uygundur." önermesine "katılıyorum" yanıtını verenlerin oran1 $(\% 34,1)$ bu kategorideki en düşük oran iken, "kararsızım" (\%23,5) ve "katılmiyorum" (\%25,9) yanıtları bu kategorideki en yüksek oranlardandır. Bu önermeye "tamamen katıllyorum" yanıtını verenlerin oranı \%15,3, "kesinlikle katılmıyorum" yanıtını verenlerin oranı ise \%1,2'dir. Bu oranlar araştırmaya katılan sosyal bilgiler öğretmenlerinin yeni programı öğrencilere üst düzey beceriler kazandırabilecek yapıda olmadığını düşündüklerini ortaya koymaktadır. Bu kategorinin "2017 SBDÖP beceri eğitimi açısından 2005 sosyal bilgiler programının daha da ilerisindedir." şeklindeki son önermesine "katıliyorum" (\%50,6) ve "tamamen katıliyorum" $(\% 16,5)$ yanıtını verenler bu kategorideki en yüksek oranlara sahiptir. Buna karşılık "karasızım" (\%15,3) ve "katılmıyorum" (\%10,6) yanıtını verenlerin oranları da bu kategorideki en düşük oranlardır. Bu önermeye "kesinlikle katılmıyorum" yanıtını verenlerin oranı \%7,0'dır. Bu yanıtlar araştırmaya katılan sosyal bilgiler öğretmenlerinin 2017 SBDÖP'nın beceri eğitimi boyutuyla 2005 SBDÖP'ndan daha iyi durumda olduğunu düşündüklerini ortaya koymaktadır.

\subsection{SBDÖP’nın Değer Eğitimi Boyutuna İlişkin Öğretmen Görüşleri}

Değer eğitimi Sosyal Bilgiler Dersi Öğretim Programlarının önemli bir unsuru olarak kabul edilmektedir. Sosyal bilgiler öğretmenlerinin 2017 SBDÖP'nın değer eğitimine ilişkin görüsslerini ortaya koymayı amaçlayan araştırmanın bu kategorisinde öğretim programının bu boyutuyla ilgili önermelere verdikleri yanıtlar aşağıda tablo hâlinde (Tablo 7) gösterilmiştir.

Tablo 7. 2017 SBDÖP’nın Değer Eğitimi Boyutuna İlişkin Öğretmen Görüşleri

\begin{tabular}{|c|c|c|c|c|c|c|c|}
\hline & & & 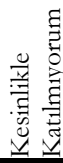 & 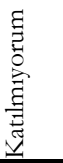 & 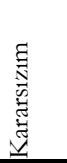 & 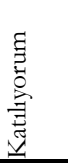 & 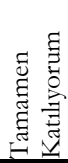 \\
\hline \multirow[t]{2}{*}{1} & 2017 SBDÖP’nda değer eğitimi ile ilgili verilen kuramsal bilgi ve açıklamalar yeterli & $\bar{f}$ & 4 & 19 & 16 & 37 & 9 \\
\hline & düzeydedir. & $\%$ & 4,7 & 22,4 & 18,8 & 43,5 & 10,6 \\
\hline \multirow[t]{2}{*}{2} & & $f$ & 4 & 19 & 9 & 40 & 13 \\
\hline & 2017 SBDÖP’nda kazandırılması öngörülen değerler sayıca yeterlidir. & $\%$ & 4,7 & 22,4 & 10,6 & 47,0 & 15,3 \\
\hline \multirow[t]{2}{*}{3} & 2017 SBDÖP, öngörülen değerleri kazandırmaya imkân verecek şekilde & $f$ & 4 & 21 & 15 & 35 & 10 \\
\hline & hazırlanmiştır. & $\%$ & 4,7 & 24,7 & 17,6 & 41,2 & 11,8 \\
\hline \multirow[t]{2}{*}{4} & & $f$ & 3 & 12 & 11 & 43 & 16 \\
\hline & 2017 SBDÖP değer eğitimi açısından 2005 SBDÖP'ndan daha ileri durumdadır. & $\%$ & 3,5 & 14,2 & 12,9 & 50,6 & 18,8 \\
\hline
\end{tabular}

Tablo 7'de görüldüğü gibi bu kategoride yer alan "2017 SBDÖP’nda değer eğitimi ile ilgili verilen kuramsal bilgi ve açılamalar yeterlidir." önermesine katılımcıların \%43,5’ "katıliyorum", \%10,6's1 ise "tamamen katıliyorum" yanıtını vermişlerdir. Bu önermeye "karasızım" yanıtını verenlerin oranı $\% 18,8$, "katılmiyorum" yanıtını verenlerin oran $1 \% 22,4$, "kesinlikle katılmıorum" yanıtını verenlerin oranı ise $\% 4,7$ 'dir. Bu önermeye "karasızım" yanıtını verenlerin oran $(\% 18,8)$ bu kategorinin en yüksek oranıdır. "2017 SBDÖP'nda kazandırılması öngörülen değerler sayıca yeterlidir." önermesine "katıliyorum" yanitını verenlerin oran1 \%47,0 "tamamen katillyorum" yanıtını verenlerin oranı ise \%15,3'tür. Bu önermeye "karasızım" yanıtını verenlerin oranı \%10,6, "katılmiyorum" yanıtını verenlerin oran1 \%22,4, "kesinlikle katılmiyorum" yanıtını verenlerin oranı ise \%4,7'dir. Bu oranlar araştırmaya katılan sosyal bilgiler öğretmenlerinin \%62,3’lük bir bölümünün programda yer alan değerleri sayıca yeterli gördüğünü ortaya koymaktadır. "2017 SBDÖP öngörülen değerleri öğrencilere kazandırmaya imkân verecek şekilde hazırlanmıştır.” şeklindeki önermeye "katılıyorum" yanıtını verenler bu kategorinin en düşük oranına $(\% 41,2)$, "tamamen katıllyorum" yanıtını verenler en yüksek ikinci orana $(\% 11,8)$, "katılmıyorum" yanıtını 
verenlerin oranı $(\% 24,7)$ ise en yüksek orana sahiptir. Bu önermeye "kararsızım" yanıtını verenlerin oran1 \%17,6, "kesinlikle katılmıyorum" yanıtını verenlerin oranı ise \%4,7'dir. "2017 SBDÖP değer eğitimi açısından 2005 SBDÖP'ndan daha ileri durumdadır." şeklindeki önermeye "katıllıyorum" $(\% 50,6)$ ve "tamamen katılıyorum" (\%18,8) yanıtları verenler bu kategorideki en yüksek oranlara; "katılmıorum" (\%14,2) ve "kesinlikle katılmıyorum" (\%3,5) yanıtını verenler ise en düşük oranlara sahiptir. Bu önermeye "karasızım" yanıtını verenlerin oranı ise \%12,9'dur. Bu yanıtlar araştırmaya katılan sosyal bilgiler öğretmenlerinin önemli ölçüde 2017 SBDÖP’nı değer eğitimi boyutuyla 2005 programından daha iyi durumda gördüklerini ortaya koymaktadır.

\subsection{SBDÖP'nın Kavram Öğretimi Boyutuna İlişkin Öğretmen Görüşleri}

Araştırmanın bu kategorisinde sosyal bilgiler öğretmenlerinin 2017 SBDÖP'nı kavram öğretimi boyutuyla ilgili görüşleri ortaya konulmaya çalışılmıştır. Bu kategoride yer alan beş adet önermeye araştırmaya katılan sosyal bilgiler öğretmenlerinin verdikleri yanıtlar aşağıda tablo hâlinde (Tablo 8) gösterilmiştir.

Tablo 8. 2017 SBDÖP’nın Kavram Öğretimi Boyutuna İlişkin Öğretmen Görüşleri

\begin{tabular}{|c|c|c|c|c|c|c|c|}
\hline & & & 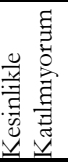 & 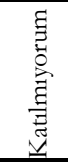 & 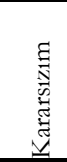 & 声 & 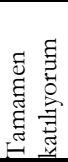 \\
\hline \multirow[t]{2}{*}{1} & \multirow[b]{2}{*}{ SBDÖP'da kavram öğretimi ile ilgili kuramsal bilgilere yer verilmelidir. } & $f$ & 2 & 14 & 7 & 50 & 12 \\
\hline & & $\%$ & 2,3 & 16,5 & 8,3 & 58,8 & 14,1 \\
\hline \multirow[t]{2}{*}{2} & \multirow{2}{*}{$\begin{array}{l}\text { SBDÖP'da sınıflar düzeyinde öğrencilere öğretilmesi gereken } \\
\text { kavramların listesine yer verilmelidir. }\end{array}$} & $\bar{f}$ & 5 & 8 & 11 & 48 & 13 \\
\hline & & $\%$ & 5,9 & 9,4 & 12,9 & 56,5 & 15,3 \\
\hline \multirow[t]{2}{*}{3} & \multirow[b]{2}{*}{ SBDÖP'da ünite-kazanım-kavram ilişkisi gösterilmelidir } & $f$ & 3 & 4 & 11 & 52 & 15 \\
\hline & & $\%$ & 3,5 & 4,7 & 12,9 & 61,3 & 17,6 \\
\hline \multirow[t]{2}{*}{4} & \multirow[b]{2}{*}{2017 SBDÖP kavram öğretimi açısından yeterlidir. } & $f$ & 5 & 13 & 24 & 27 & 16 \\
\hline & & $\%$ & 5,9 & 15,3 & 28,2 & 31,8 & 18,8 \\
\hline \multirow[t]{2}{*}{5} & \multirow{2}{*}{$\begin{array}{l}2017 \text { SBDÖP kavram öğretimi açısından } 2005 \text { SBDÖP'dan daha ileri } \\
\text { durumdadır. }\end{array}$} & $\bar{f}$ & 3 & 10 & 10 & 49 & 13 \\
\hline & & $\%$ & 3,5 & 11,8 & 11,8 & 57,6 & 15,3 \\
\hline
\end{tabular}

Tablo 8'de de görüldüğü gibi "SBDÖP’'nda kavram öğretimi ile ilgili kuramsal bilgilere yer verilmelidir." önermesine "katılıyorum" yanıtını verenlerin oranı \%58,8, "tamamen katillyorum" yanıtını verenlerin oranı ise \%14,1'dir. Toplam \%72,9'a karşılık gelen bu oran araştırmaya katılan öğretmenlerin önemli ölçüde öğretim programında kavram öğretimi ile ilgili teorik bilgilerin yer alması gerektiğini düşündüklerini ortaya koymaktadır. Bu önermeye "kararsızım" (\%8,3) ve "kesinlikle katılmıyorum" (\%2,3) yanıtını verenler bu kategorideki en düşük; "katılmıorum" $(\% 16,5)$ yanıtını verenler ise en yüksek orana sahiptir. "SBDÖP’nda sınıflar düzeyinde öğrencilere öğretilmesi gereken kavramların listesine yer verilmelidir." önermesine "katılıyorum" yanıtını verenler \%12,9, "katılmiyorum" yanıtını verenler \%9,4, "kesinlikle katılmiyorum" yanitını verenler ise \% 5,9 'luk orana sahiptir. "SBDÖP'da ünite-kazanım-kavram ilişkisi gösterilmelidir." önermesine "katılıyorum" yanıtını verenler bu kategorinin en yüksek oranına $(\% 61,3)$ sahip iken "tamamen katiliyorum" yanitını verenler \%17,6, "kararsızım" yanitını verenler \%3,5, "katilmiyorum" yanitını verenler ise \%4,7'lik bir orana sahiptir. "2017 SBDÖP kavram öğretimi açısından yeterlidir." önermesine "katıllyorum" $(\% 31,8)$ yanıtını verenlerin oranı bu kategorinin açık ara en düşük oran iken, "karasızım" yanıtını verenler $(\% 28,2)$ ve "tamamen katılıyorum $(\% 18,8)$ yanitını verenler bu kategorideki en yüksek oranlara sahiptir. Bu önermeye ayrıca "katılmıyorum" yanıtını verenlerin oranı \%15,3 iken, "kesinlikle katılmıyorum" yanıtını verenler \%5,9 ile bu kategorideki en yüksek orana sahiptir. Bu sonuçlar araştırmaya katılan sosyal bilgiler öğretmenlerinin yaklaşık yarısının 2017 SBDÖP’nı kavram öğretimi açısından yeterli bulmadıklarını ortaya koymaktadır. Bu kategorinin “2017 SBDÖP kavram öğretimi açısından 2005 SBDÖP'dan daha ileri durumdadır." şeklindeki son önermesine "kat1liyorum" (\%57,6) ve "tamamen kat1lyorum" (\%15,3) yanitını verenlerin toplam oranı \%72,9 gibi yüksek bir düzeydedir. Bu önermeye "kararsızım" yanıtı verenler \%11,8, 
TURAN, Refik (2020). “2017 Sosyal Bilgiler Dersi Öğretim Programına İlişkin Öğretmen Görüşleri (Aksaray İli Örneği)", Mavi Atlas, 8(2): 256-277

"katılmıorum" yanıtını verenler \%11,8, "kesinlikle katılmıyorum" yanıtını verenler ise \%3,5’lik orana sahiptir.

\section{Görüşleri \\ 3.5. 2017 SBDÖP’nın Ölçme ve Değerlendirme Boyutuna İlişkin Öğretmen}

2017 SBDÖP’nın ölçme ve değerlendirme boyutuna ilişkin öğretmen görüşlerinin saptanmasına yönelik bu kategoride yer alan dört önermeye araştırmaya katılan öğretmenlerin verdikleri yanıtlar aşağıda tablo hâlinde (Tablo 9) gösterilmiştir.

Tablo 9. 2017 SBDÖP’nın Ölçme ve Değerlendirme Boyutuna İlişkin Öğretmen Görüşleri

\begin{tabular}{|c|c|c|c|c|c|c|}
\hline & & 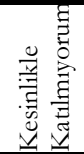 & 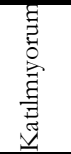 & 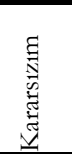 & 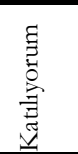 & 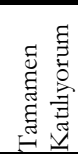 \\
\hline $\begin{array}{l}1 \text { SBDÖP'da ölçme ve değerlendirme yöntem ve teknikleri ile ilgili bilgilere } \\
\text { verilmelidir. }\end{array}$ & $\begin{array}{l}f \\
\%\end{array}$ & $\begin{array}{l}2 \\
2,3\end{array}$ & $\begin{array}{l}15 \\
17,6\end{array}$ & $\begin{array}{l}7 \\
8,3\end{array}$ & $\begin{array}{l}44 \\
51,8\end{array}$ & $\begin{array}{l}17 \\
20,0\end{array}$ \\
\hline $\begin{array}{ll}2 & \text { SBDÖP’nda üniteler bazında kullanılabilecek ölçme ve değerlendirme teknikleri } \\
\text { ilgili önerilere yer verilmelidir. }\end{array}$ & $\begin{array}{l}f \\
\%\end{array}$ & $\begin{array}{l}5 \\
5,9\end{array}$ & $\begin{array}{l}8 \\
9,4 \\
\end{array}$ & $\begin{array}{l}9 \\
10,6 \\
\end{array}$ & $\begin{array}{l}49 \\
57,6\end{array}$ & $\begin{array}{l}14 \\
16,5 \\
\end{array}$ \\
\hline $\begin{array}{l}32017 \text { SBDÖP'da ölçme ve değerlendirme ile ilgili yer verilen açılama ve temel-teo } \\
\text { bilgiler yeterli düzeydedir. }\end{array}$ & $\begin{array}{l}f \\
\%\end{array}$ & $\begin{array}{l}3 \\
3,5 \\
\end{array}$ & $\begin{array}{l}9 \\
10,6 \\
\end{array}$ & $\begin{array}{l}7 \\
8,3 \\
\end{array}$ & $\begin{array}{l}49 \\
57,6 \\
\end{array}$ & $\begin{array}{l}17 \\
20,0 \\
\end{array}$ \\
\hline $\begin{array}{l}2017 \text { SBDÖP ölçme ve değerlendirme boyutuyla } 2005 \text { SBDÖP'dan daha işlevsel } \\
\text { ileri durumdadır. }\end{array}$ & $\begin{array}{l}f \\
\%\end{array}$ & $\begin{array}{l}4 \\
4,7\end{array}$ & $\begin{array}{l}12 \\
14,1\end{array}$ & $\begin{array}{l}11 \\
12,9\end{array}$ & $\begin{array}{l}39 \\
45,9\end{array}$ & $\begin{array}{l}19 \\
22,4\end{array}$ \\
\hline
\end{tabular}

Tablo 9'da da görüldüğü gibi araştırmanın bu kategorisinde yer alan önermelerden "SBDÖP’nda ölçme ve değerlendirme yöntem ve teknikleri ile ilgili bilgilere yer verilmelidir." önermesine "katıllyorum" yanıtını verenler \% $\% 1,8$, "tamamen katıliyorum" yanıtını verenler \%20,0, "kararsızım" yanitını verenler \%8,3, "katılmiyorum" yanitını verenler \%17,6, "kesinlikle katılmıorum" yanıtını verenler ise $\% 2,3$ 'lük orana sahiptir. Bu önermeye "katılmıyorum" yanıtını verenlerin oranı $(\% 17,6)$ bu kategorideki en yüksek orandır. "SBDÖP'da üniteler bazında kullanılabilecek ölçme ve değerlendirme teknikleri ile ilgili önerilere yer verilmelidir." şeklindeki önermeye "katıliyorum" (\%57,6) ve "tamamen katiliyorum" (\%16,5) yanitını verenlerin toplam oranı \%74,1'dir. Bu önermeye "kararsızım" yanıtını verenler \%10,6, "katılmıyorum" yanıtını verenler $\% 9,4$, "kesinlikle katılmıorum" yanıtını verenler ise $\% 5,9$ 'luk orana sahiptir. Bu sonuçlar araştırmaya katılan sosyal bilgiler öğretmenlerinin yaklaşık dörtte üçünün sosyal bilgiler dersi öğretim programında ölçme-değerlendirme yöntem ve teknikleri ile derslerde kullanılabilecek ölçme-değerlendirme önerilerine yer verilmesi gerektiği düşüncesinde olduklarını ortaya koymaktadır. "2017 SBDÖP'da "ölçme ve değerlendirme” ile ilgili yer verilen açıklama ve temelteorik bilgiler yeterli düzeydedir." şeklindeki önermeye "katıllyorum" (\%57,6) ve "tamamen katılıyorum" (\%20) yanıtını verenlerin toplam oranı \%77,6 düzeyindedir. Buna karşılık "karasızım" yanitını verenler $\% 8,3$, "katılmiyorum" yanitını verenler $\% 10,6$, "kesinlikle katılmiyorum" yanıtını verenlerin oran ise \%3,5'lik orana sahiptir. Bu önermeye "katıliyorum" (\%57,6) ve "tamamen katılıyorum" (\%20,0) yanıtını verenlerin toplam oranı bu kategorinin en yüksek oranıdır. "2017 SBDÖP ölçme ve değerlendirme boyutuyla 2005 SBDÖP'dan daha işlevsel ve ileri durumdadır." şeklindeki önermeye "katılıyorum" yanıtını verenlerin oranı $(\% 45,9)$ bu kategorideki en düşük, "tamamen katıllyorum" yanıtını verenlerin oranı $(\% 22,4)$ ise en yüksek düzeydedir. Bu önermeye ayrica "kararsizım" yanıtı verenler \%12,9, "katılmıyorum" yanıtını verenler \%14,1, "kesinlikle katılmıorum" yanıtını verenler ise \%5,9'luk orana sahiptir. Bu son iki önermeye verilen yanıtlar araştırmaya katılan sosyal bilgiler öğretmenlerinin 2017 SBDÖP'da yer alan ölçme ve değerlendirme ile ilgili açıklama ve temel teorik bilgileri yeterli gördüklerini ve program bu boyutuyla 2005 programına oranla daha iyi durumda gördüklerini ortaya koymaktadır. 
TURAN, Refik (2020). “2017 Sosyal Bilgiler Dersi Öğretim Programına İlişkin Öğretmen Görüşleri (Aksaray İli Örneği)", Mavi Atlas, 8(2): 256-277

\subsection{SBDÖP'nın Öğrenme Alanı, Ünite ve Kazanım Boyutlarına İlişkin Öğretmen Görüşleri}

Araştırmaya katılan sosyal bilgiler öğretmenlerinin 2017 SBDÖP'nın öğrenme alanları, ünite ve kazanım boyutlarına ilişkin soru formunda yer alan önermelere verdikleri yanıtlar aşağıda tablo hâlinde (Tablo 10) gösterilmiştir.

Tablo 10. 2017 SBDÖP’nın Öğrenme Alanı, Ünite ve Kazanım Boyutlarına İlişkin Öğretmen Görüşleri

\begin{tabular}{|c|c|c|c|c|c|c|c|}
\hline & & & 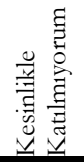 & 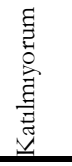 & 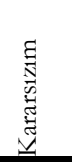 &  & 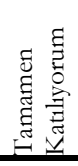 \\
\hline 1 & $\begin{array}{l}2017 \text { SBDÖP'da yer verilen öğrenme alanları bireyin içinde yaşadı̆̆ı sosyal } \\
\text { hayatın her alanını yeterince kapsamaktadır. }\end{array}$ & $\begin{array}{l}F \\
\%\end{array}$ & $\begin{array}{l}4 \\
4,7 \\
\end{array}$ & $\begin{array}{l}15 \\
17,6 \\
\end{array}$ & $\begin{array}{l}15 \\
17,6 \\
\end{array}$ & $\begin{array}{l}39 \\
45,9 \\
\end{array}$ & $\begin{array}{l}12 \\
14,1\end{array}$ \\
\hline 2 & $\begin{array}{l}2017 \text { SBDÖP'nda yer verilen öğrenme alanları dersin amaçlarını } \\
\text { gerçekleştirmeye imkân verecek şekilde belirlenmiştir. }\end{array}$ & $\begin{array}{l}f \\
\% \\
\end{array}$ & $\begin{array}{l}7 \\
8,3 \\
\end{array}$ & $\begin{array}{l}11 \\
12,9 \\
\end{array}$ & $\begin{array}{l}12 \\
14,1 \\
\end{array}$ & $\begin{array}{l}39 \\
45,9 \\
\end{array}$ & $\begin{array}{l}16 \\
18,8 \\
\end{array}$ \\
\hline 3 & $\begin{array}{l}2017 \text { SBDÖP öğrenme alanları bakımından } 2005 \text { SBDÖP'ndan daha } \\
\text { işlevsel ve ileri durumdadır. }\end{array}$ & $\begin{array}{l}f \\
\%\end{array}$ & $\begin{array}{l}4 \\
4,7\end{array}$ & $\begin{array}{l}17 \\
20,0\end{array}$ & $\begin{array}{l}10 \\
11,8 \\
\end{array}$ & $\begin{array}{l}40 \\
47,1\end{array}$ & $\begin{array}{l}14 \\
16,4\end{array}$ \\
\hline 4 & $\begin{array}{l}2017 \text { SBDÖP'da ünite yapılandırmasına gidilmeyerek ünite } \\
\text { yapılandırmasının ders kitabı yazarı ve yayınevlerine bırakılmış olması } \\
\text { doğru ve yerinde bir uygulamadır. }\end{array}$ & $\begin{array}{l}f \\
\%\end{array}$ & $\begin{array}{l}6 \\
7,1\end{array}$ & $\begin{array}{l}20 \\
23,5\end{array}$ & $\begin{array}{l}18 \\
21,2\end{array}$ & $\begin{array}{l}29 \\
34,1\end{array}$ & $\begin{array}{l}12 \\
14,1\end{array}$ \\
\hline 5 & 2017 SBDÖP kazanım sayısı bakımından yeterli düzeydedir. & $\begin{array}{l}f \\
\%\end{array}$ & $\begin{array}{l}5 \\
5,9\end{array}$ & $\begin{array}{l}14 \\
16,5\end{array}$ & $\begin{array}{l}6 \\
7,0\end{array}$ & $\begin{array}{l}44 \\
51,8\end{array}$ & $\begin{array}{l}16 \\
18,8\end{array}$ \\
\hline 6 & 2017 SBDÖP’nda yer alan kazanımlar kapsam açısından yeterlidir. & $\begin{array}{l}f \\
\% \\
\end{array}$ & $\begin{array}{l}5 \\
5,9 \\
\end{array}$ & $\begin{array}{l}13 \\
15,3 \\
\end{array}$ & $\begin{array}{ll}11 \\
12,9 \\
\end{array}$ & $\begin{array}{l}40 \\
47,1 \\
\end{array}$ & $\begin{array}{ll}16 \\
18,8 \\
\end{array}$ \\
\hline 7 & $\begin{array}{l}2017 \text { SBDÖP'da kazanım sayılarının azaltılması doğru ve yerinde bir } \\
\text { uygulama olmuştur. }\end{array}$ & $\begin{array}{l}f \\
\% \\
\end{array}$ & $\begin{array}{l}6 \\
7,1 \\
\end{array}$ & $\begin{array}{l}12 \\
14,1 \\
\end{array}$ & $\begin{array}{l}5 \\
5,9 \\
\end{array}$ & $\begin{array}{l}42 \\
49,4 \\
\end{array}$ & $\begin{array}{l}20 \\
23,5 \\
\end{array}$ \\
\hline 8 & $\begin{array}{l}2017 \text { SBDÖP'nda yer alan kazanımlar öğrencilerin bilişsel, duyuşsal ve } \\
\text { psikomotor gelişim düzeylerine uygundur. }\end{array}$ & $\begin{array}{l}f \\
\% \\
\end{array}$ & $\begin{array}{l}2 \\
2,4 \\
\end{array}$ & $\begin{array}{l}12 \\
14,1 \\
\end{array}$ & $\begin{array}{l}12 \\
14,1 \\
\end{array}$ & $\begin{array}{l}43 \\
50,6 \\
\end{array}$ & $\begin{array}{l}16 \\
18,8 \\
\end{array}$ \\
\hline 9 & $\begin{array}{l}2017 \text { SBDÖP'nda yer alan kazanımlar gerçek hayata uyarlanabilir } \\
\text { niteliktedir. }\end{array}$ & $\begin{array}{l}f \\
\% \\
\end{array}$ & $\begin{array}{l}1 \\
1,2 \\
\end{array}$ & $\begin{array}{l}13 \\
15,3 \\
\end{array}$ & $\begin{array}{l}14 \\
16,4 \\
\end{array}$ & $\begin{array}{l}38 \\
44,7 \\
\end{array}$ & $\begin{array}{l}19 \\
16,5 \\
\end{array}$ \\
\hline 10 & 2017 SBDÖP’ndaki kazanımlar öğrencilerin ilgisini çekecek niteliktedir. & $\begin{array}{l}f \\
\% \\
\end{array}$ & $\begin{array}{l}8 \\
9,4 \\
\end{array}$ & $\begin{array}{l}9 \\
10,6 \\
\end{array}$ & $\begin{array}{l}16 \\
18,8 \\
\end{array}$ & $\begin{array}{l}38 \\
44,7 \\
\end{array}$ & $\begin{array}{l}14 \\
16,5 \\
\end{array}$ \\
\hline 11 & 2017 SBDÖP’nda kazanımlar için belirlenen süreler yeterlidir. & $\begin{array}{l}f \\
\% \\
\end{array}$ & $\begin{array}{l}18 \\
21,2 \\
\end{array}$ & $\begin{array}{l}16 \\
18,9 \\
\end{array}$ & $\begin{array}{l}11 \\
12,9 \\
\end{array}$ & $\begin{array}{l}32 \\
37,6 \\
\end{array}$ & $\begin{array}{l}8 \\
9,4 \\
\end{array}$ \\
\hline 12 & $\begin{array}{l}2017 \text { SBDÖP'da kazanımlar Atatürkçülük konuları ile yeterince } \\
\text { iliş̧kilendirilmiştir. }\end{array}$ & $\begin{array}{l}f \\
\% \\
\end{array}$ & $\begin{array}{l}7 \\
8,2 \\
\end{array}$ & $\begin{array}{l}21 \\
24,7 \\
\end{array}$ & $\begin{array}{l}8 \\
9,4 \\
\end{array}$ & $\begin{array}{l}32 \\
37,6 \\
\end{array}$ & $\begin{array}{l}18 \\
21,1 \\
\end{array}$ \\
\hline 13 & $\begin{array}{l}2017 \text { SBDÖP’nda Atatürkçülük ile ilgili kazanımlar sayı ve kapsam } \\
\text { bakımından yeterlidir }\end{array}$ & $\begin{array}{l}f \\
\%\end{array}$ & $\begin{array}{l}3 \\
3,5\end{array}$ & $\begin{array}{l}22 \\
25,9\end{array}$ & $\begin{array}{l}13 \\
15,3\end{array}$ & $\begin{array}{l}27 \\
31,8\end{array}$ & $\begin{array}{l}20 \\
23,5\end{array}$ \\
\hline
\end{tabular}

Yukarıdaki tabloda da görüldüğü gibi araştırmaya katılan sosyal bilgiler öğretmenlerinin bu kategoride yer alan on üç önermeye verdikleri yanıtlar şöyledir: "2017 SBDÖP'da yer verilen öğrenme alanları bireyin içinde yaşadığı sosyal hayatın her alanını yeterince kapsamaktadır." önermesine "katıllyorum" yanıtını verenler \% 45,9 , "tamamen katıllyorum" yanıtını verenler \% 14,1 , "katılmiyorum" yanıtını verenler \%17,6, "kesinlikle katılmiyorum" yanıtını verenler \%4,7’lik orana sahiptir. Bu önermeye "kararsızım" yanıtını verenler ise \%17,6 gibi yüksek bir orandadır. "2017 SBDÖP'da yer verilen öğrenme alanları dersin amaçlarını gerçekleştirmeye imkân verecek şekilde belirlenmiştir." şeklindeki önermeye "katıllyorum" (\%45,9) ve "tamamen katıllyorum" (\%18,8) yanitını verenlerin toplam oran $\% 64,7$ iken; "katilmiyorum" $(\% 12,9)$ ve "kesinlikle katilmiyorum" $(\% 18,8)$ yanıtını verenlerin toplam oran $\% 21,6$ 'dır. Bu önermeye "kararsızım" yanıtını verenlerin oran1 \%14,1'dir. "2017 SBDÖP öğrenme alanları bakımından 2005 SBDÖP’ndan işlevsel ve ileri durumdadır." önermesine "katılıyorum" yanitını verenler \% 47,1 , "tamamen katılıyorum" yanıtını verenler \%16,4, "katılmiyorum" yanitını verenler \%20,0, "kesinlikle katılmıyorum" yanitını verenler \%4,7, "kararsızım" yanıtını verenler ise \%11,8'lik orana sahiptir. "2017 SBDÖP'da ünite yapılandırmasına gidilmeyerek ünite yapılandırmasının ders kitabı yazarı ve yayınevlerine bırakılmış olması doğru ve yerinde bir uygulamadır" önermesine "katılıyorum" yanıtını verenlerin oranı \%34,1 
ile bu kategorideki en düşük oranlardan birisi iken, "katılmıyorum" yanıtını verenlerin oranı $(\% 23,5)$ bu kategorideki en yüksek orandır. Bu önermeye "tamamen katılıyorum" yanıtını verenlerin oranı $\% 14,1$, "kesinlikle katılmıyorum" yanıtını verenlerin oranı $\% 7,1$, "karasızım" yanıtını verenlerin oranı ise \%21,2'dir. "2017 SBDÖP kazanım sayısı bakımından yeterli düzeydedir." önermesine "katılıyorum" yanıtını verenlerin oran $1 \% 51,8$ ile bu kategorideki en yüksek oran iken, "tamamen katılıyorum" yanıtını verenlerin oranı da \%18,8 gibi yüksek bir düzeydedir. Bu önermeye "katılmiyorum" yanıtını verenler \%16,5, "kesinlikle katılmiyorum" yanıtını verenler \%5,9, "kararsızım" yanıtını verenler ise \%7,0'lik bir orana sahiptir. "2017 SBDÖP'da yer alan kazanımlar kapsam açısından yeterlidir." önermesine "katıliyorum" yanıtını verenlerin oranı \% 47,1, "tamamen katıllyorum" yanitinı verenlerin oran1 \%18,8, "katılmiyorum" yanitını verenlerin oran1 \%15,3, "kesinlikle katılmıyorum" yanıtını verenlerin oranı $\% 5,9$, "kararsızım" yanıtını verenlerin oranı ise \%12,9'dur. "2017 SBDÖP'da kazanım sayılarının azaltılması doğru ve yerinde bir uygulama olmuştur." önermesine "katıllyorum" yanıtını verenlerin oranı \%49,4 olup bu kategorideki en yüksek oranlardan birisi iken "tamamen katiliyorum" yanıtını verenlerin oran1 da \%23,5 ile bu kategorinin en yüksek oranıdır. Bu önermeye katılmıyorum yanıtını verenlerin oran1 \%14,1, "kesinlikle katılmıyorum" yanıtını verenlerin oranı $\% 7,1$, "kararsızım" yanıtını verenlerin oranı ise \%5,9'dur. "2017 SBDÖP'da yer alan kazanımlar öğrencilerin bilişsel, duyuşsal ve psikomotor gelişim düzeylerine uygundur." önermesine "katıliyorum" yanıtı verenler \%50,6, "tamamen katilıyorum" yanit1 verenler \%18,8, "katılmiyorum" yanit1 verenler \%14,1, "kesinlikle katılmıorum" yanıtı verenler $\% 2,4$, "kararsızım" yanıtını verenler ise $\% 14,1$ 'lik orana sahiptir. Bu önermeye verilen "katılmıorum" ve "kesinlikle katılmıyorum" yanıtları bu kategorinin en düşük oranlardır. "2017 SBDÖP'da yer alan kazanımlar gerçek hayata uyarlanabilir niteliktedir." önermesine "katılıyorum" yanitını verenlerin oranı \%44,7, "tamamen katilıyorum" yanıtını verenlerin oran1 $\% 22,4$, "katılmıorum" yanıtını verenlerin oran $\% 15,3$, "kesinlikle katılmıorum" yanıtını verenlerin oranı $\% 1,2$, "kararsızım" yanıtını verenlerin oranı ise $\% 16,4$ 'tür. Bu önermeye "tamamen katılıyorum" yanıtını verenlerin oranı bu kategorideki en yüksek oranlardan birisi iken "kesinlikle katılmıyorum" yanıtını verenlerin oranı bu kategorinin en düşük oranıdır. "2017 SBDÖP’ndaki kazanımlar öğrencilerin ilgisini çekecek niteliktedir.” önermesine verilen yanıtlardan "katılıyorum" \%44,7, "tamamen katılıyorum" \%16,5, "katılmiyorum" \%10,6, "kesinlikle katılmıorum" \%9,4, "kararsızım" ise \%18,8'lik bir orana sahiptir. Bu önermeye "kesinlikle katılmıyorum" ve "kararsızım" yanıtını verenler bu kategorideki en yüksek oranlar arasındadır. “2017 SBDÖP'nda kazanımlar için belirlenen süreler yeterlidir.” önermesine "katılıyorum” yanıtını verenlerin oranı \%25,8 olup bu kategorideki en düşük oran iken, "tamamen katıllyorum" yanıtını verenler \%21,2 gibi oldukça yüksek bir orandadır. Bu önermeye "katılmıyorum" yanıtını verenlerin oranı \%18,9, "kesinlikle katılmıyorum" yanıtını verenlerin oranı ise $\% 21,2$ 'dir ki bu oran aynı zamanda tüm kategorilerdeki en yüksek orandır. Bu önermeye "kararsızım" yanıtını verenlerin oranı \%12,9’dur. "2017 SBDÖP’nda kazanımlar Atatürkçülük konuları ile yeterince ilişkilendirilmiştir.” önermesine "katıllyorum" yanitını verenlerin oranı \%37,6, "tamamen katilıorum" yanitını verenlerin oranı ise \%20,0'dır. Buna karşılık "katılmıyorum" yanıtını verenlerin oranı bu kategorideki en yüksek oran olan \%24,72dür. Bu önermeye "kesinlikle katılmıyorum" yanıtını verenlerin oranı \%8,2, "kararsızım" yanıtını verenlerin oranı ise \%9,4'tür. "2017 SBDÖP'nda Atatürkçülük ile ilgili kazanımlar sayı ve kapsam bakımından yeterlidir." şeklindeki önermeye "katiliyorum" (\%31,8) ve "tamamen kat1liyorum" $(\% 23,5)$ yanitın verenlerin toplam oran $\% 55,3$ iken, "katılmıyorum" yanıtını verenlerin oranı $\% 25,9$, ile bu kategorideki en yüksek düzeydir. Bu önermeye "kesinlikle katılmıyorum" yanıtını verenlerin oran $1 \% 3,5$, "kararsızım" yanıtını verenlerin oran 1 ise $\% 15,3$ 'tür.

2017 SBDÖP'nın önceki programdan ayrılan bir başka yönü de programda ünite yapılandırmasına gidilmeyerek bu işin ders kitabı yazarları ve yayınevlerine bırakılmış olmasıdır. Araştırmaya katılan sosyal bilgiler öğretmenlerinin sadece $\% 48,2$ 'si bu uygulamayı doğru ve yerinde 
bir uygulama olarak görmektedir. Araştırma bulguları katılımcıların önemli bir kısmının program kazanımlarının öğrencilerin bilişsel, duyuşsal ve psikomotor gelişim düzeylerine uygun $(\% 69,4)$, gerçek hayata uyarlanabilir $(\% 61,2)$, öğrencilerin ilgisini çekebilecek nitelikte $(\% 61,2)$ ve kapsam $(\% 65,9)$ ve sayı $(\% 70,6)$ bakımlarından yeterli bulduklarını ortaya koymaktadır. Öğretmenlerin \%72,9'u 2017 SBDÖP'nda kazanım sayısının azaltılmasını doğru ve yerinde bir uygulama olarak görürken, yarısından daha az bir bölümü $(\% 47,0)$ kazanımlar için belirlenen süreleri yeterli bulmaktadırlar. Yine araştırmaya katılan öğretmenlerin \%58,7'si kazanımların Atatürkçülük konuları ile yeterince ilişkilendirilmiş olduğunu, \%55,3’ü ise programda yer alan Atatürkçülük ile ilgili kazanım sayısını ve kapsamını yeterli görmektedir.

\subsection{SBDÖP’nın İlişkilendirmeler Boyutuna İlişkin Öğretmen Görüşleri}

2017 SBDÖP’nın “ilişskilendirmeler” boyutuna yönelik öğretmen görüşlerinin ortaya konulmasının amaçlandığ araştırmanın bu kategorisinde araştırmaya katılan sosyal bilgiler öğretmenlerinin verdikleri yanıtlar aşağıda tablo hâlinde gösterilmiştir.

Tablo 11. 2017 SBDÖP'nın İlişkilendirmeler Boyutuna İlişkin Öğretmen Görüşleri

\begin{tabular}{|c|c|c|c|c|c|c|c|}
\hline & & & 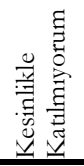 & 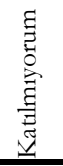 & 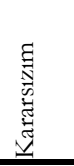 & 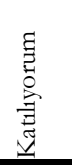 & 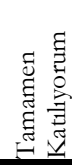 \\
\hline \multirow[t]{2}{*}{1} & & $f$ & 5 & 5 & 9 & 38 & 28 \\
\hline & SBDÖP'nda ders içi ilişkilendirmelere yer verilmelidir. & $\%$ & 5,9 & 5,9 & 10,6 & 44,7 & 32,9 \\
\hline \multirow[t]{2}{*}{2} & & $\bar{f}$ & 4 & $\overline{4}$ & 10 & 40 & 27 \\
\hline & SBDÖP'nda diğer derslerle ilişkilendirmelere yer verilmelidir. & $\%$ & 4,7 & 4,7 & 11,8 & 47,0 & 31,8 \\
\hline \multirow[t]{2}{*}{3} & & $f$ & 4 & 4 & 6 & 42 & 28 \\
\hline & SBDÖP’nda ara disiplinlerle ilişkkilendirmelere yer verilmelidir. & $\%$ & 4,7 & 4,7 & 7,0 & 49,4 & 32,9 \\
\hline
\end{tabular}

Tablo 11'de de görüldüğü gibi “SBDÖP'nda ders içi ilişkilendirmelere yer verilmelidir.” önermesine "katıllyorum" yanitını verenlerin oran1 \%44,7, "tamamen katiliyorum" yanitını verenlerin oranı \%32,9, "katılmıyorum" ve "kesinlikle katılmiyorum" yanitını verenlerin oranı $\% 5,9$, "kararsızım" yanıtını verenlerin oranı ise \%10,6'dır. Bu önermeye "tamamen katiliyorum" yanıtını verenler bu kategorideki en yüksek orana sahiptir. "SBDÖP'nda diğer derslerle ilişkilendirmelere yer verilmelidir." önermesine "katıllyorum" yanıtını verenlerin oranı \% $\% 7,0$, "tamamen katilıyorum" yanitını verenlerin oran1 \%31,8, "katılmiyorum" ve "kesinlikle katılmiyorum" yanıtını verenlerin oran $1 \% 4,7$, "kararsızım" yanıtını verenlerin oran 1 ise $\% 11,8$ ' dir. "SBDÖP'da ara disiplinlerle ilişkilendirmelere yer verilmelidir." şeklindeki önermeye "kattliyorum" $(\% 49,4)$ ve "tamamen katıliyorum" (\%32,9) yanıtını verenlerin oranı bu kategorideki en yüksek oranlardır. Bu önermeye "katılmıyorum" ve "kesinlikle katılmıyorum" yanıtını verenlerin oranı $\% 4,7$, "kararsızım" yanıtını verenlerin oranı ise $\% 7,0$ 'dır.

\subsection{SBDÖP’nın Kazanım Tablosuna İlişkin Öğretmen Görüşleri}

2017 SBDÖP'nın kazanım tablosunun özellikleriyle ilgili öğretmen görüşlerine yer verilen araştırmanın bu kategorisinde katılımcıların verdikleri yanıtlar aşağıda tablo hâlinde (Tablo 12) gösterilmiştir.

Tablo 12. 2017 SBDÖP’nın Kazanım Tablosuna Yönelik Öğretmen Görüşleri

\begin{tabular}{|c|c|c|c|c|c|c|c|c|}
\hline & & & & & 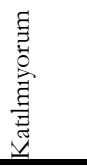 & 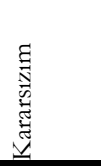 & 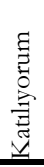 & 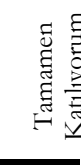 \\
\hline 1 & $\begin{array}{l}\text { SBDÖP'nın kazanım tablosunda ünite ve kazanımlarla bağlantılı olarak } \\
\text { materyal önerilerine yer verilmelidir. }\end{array}$ & $\begin{array}{l}f \\
\%\end{array}$ & $\begin{array}{l}3 \\
3,5\end{array}$ & $\begin{array}{l}8 \\
9,4 \\
\end{array}$ & $\begin{array}{l}5 \\
5,9 \\
\end{array}$ & $\begin{array}{l}43 \\
50,6 \\
\end{array}$ & & $\begin{array}{l}26 \\
30,6\end{array}$ \\
\hline 2 & $\begin{array}{l}\text { SBDÖP'nın kazanım tablosunda ünite ve kazanımlarla bağlantılı olarak } \\
\text { sınıf-okul içi etkinlik önerilerine yer verilmelidir. }\end{array}$ & $\begin{array}{l}f \\
\%\end{array}$ & $\begin{array}{l}1 \\
1,2\end{array}$ & $\begin{array}{l}8 \\
9,4\end{array}$ & $\begin{array}{l}4 \\
4,7\end{array}$ & $\begin{array}{l}43 \\
50,6\end{array}$ & & $\begin{array}{r}29 \\
34,1\end{array}$ \\
\hline 3 & & $f$ & 1 & 6 & 9 & 44 & & 25 \\
\hline
\end{tabular}




\begin{tabular}{|c|c|c|c|c|c|c|c|}
\hline & $\begin{array}{l}\text { SBDÖP'nın kazanım tablosunda ünite ve kazanımlarla bağlantılı olarak } \\
\text { okul dışı etkinlik-inceleme gezisi önerilerine yer verilmelidir. }\end{array}$ & $\%$ & 1,2 & 7,0 & 10,6 & 51,8 & 29,4 \\
\hline 4 & $\begin{array}{l}\text { SBDÖP'nın kazanım tablosunda ünite ve kazanımlarla bağlantılı olarak } \\
\text { kullanılabilecek yöntem ve teknik önerilerine yer verilmelidir. }\end{array}$ & $\begin{array}{l}f \\
\%\end{array}$ & $\begin{array}{c}2 \\
2,4 \\
\end{array}$ & $\begin{array}{l}6 \\
7,0\end{array}$ & $\begin{array}{l}9 \\
10,6\end{array}$ & $\begin{array}{l}35 \\
45,2\end{array}$ & $\begin{array}{r}33 \\
38,8\end{array}$ \\
\hline 5 & $\begin{array}{l}2017 \text { SBDÖP program kitapçı̆̆ı genel olarak sade ve işlevsel hazırlanmış } \\
\text { olup öğretmenlere kullanım kolaylığı sağlamaktadır. }\end{array}$ & $\begin{array}{l}f \\
\%\end{array}$ & $\begin{array}{l}5 \\
5,9\end{array}$ & $\begin{array}{l}9 \\
10,6\end{array}$ & $\begin{array}{l}11 \\
12,9\end{array}$ & $\begin{array}{l}36 \\
42,4\end{array}$ & $\begin{array}{r}24 \\
28,2\end{array}$ \\
\hline
\end{tabular}

Tablo 12'de de görüldüğü üzere "SBDÖP'nın kazanım tablosunda ünite ve kazanımlarla bağlantılı olarak materyal önerilerine yer verilmelidir." şeklindeki önermeye "katıllyorum" yanıtını verenlerin oran1 \%50,6, "tamamen katıliyorum" yanıtını verenlerin oranı \%30,6, "katılmiyorum" yanitını verenlerin oranı \%9,4, "kesinlikle katılmiyorum" yanıtın1 verenlerin oran1 \%3,5, "kararsızım" yanıtını verenlerin oranı ise \%5,9'dur. "SBDÖP'nın kazanım tablosunda ünite ve kazanımlarla bağlantılı olarak sınıf-okul içi etkinlik önerilerinde bulunulmalıdır." önermesine "kat1liyorum" (\%50,6) ve "kesinlikle katıliyorum" (\%34,1) yanitını verenlerin toplam oran $\% 84,7$ gibi oldukça yüksek bir düzeydedir. Bu önermeye "kararsızım" yanıtını verenlerin oranı $(\% 4,7)$ bu kategorideki en düşük oran iken, "katılmıyorum" yanıtını verenlerin oranı $\% 9,4$, "kesinlikle katılmıorum" yanıtını verenlerin oranı ise \%1,2'dir. "SBDÖP'nın kazanım tablosunda ünite ve kazanımlarla bağlantılı olarak okul dışı etkinlik-inceleme gezisi önerilerine yer verilmelidir." önermesine "katıliyorum" yanitını verenlerin oran1 \%51,8, "tamamen katiliyorum" yanıtını verenlerin oran $1 \% 29,4$, "katılmiyorum" yanitını verenlerin oran1 $\% 7$, "kesinlikle katilmiyorum" yanıtını verenlerin oranı \%1,2, "kararsızım" yanıtını verenlerin oranı ise \%10,6'dır. "SBDÖP'nın kazanım tablosunda ünite ve kazanımlarla bağlantılı olarak kullanılabilecek yöntem ve teknik önerilerine yer verilmelidir." önermesine "katılıyorum" yanıtını verenlerin oran $1 \% 45,2$, "tamamen katıliyorum" yanıtını verenlerin oran $\% 38,8$, "katılmıyorum" yanıtını verenlerin oran $\% 7,0$, "kesinlikle katılmıyorum" yanıtını verenlerin oranı \% 2,4 , "kararsızım" yanıtını verenlerin oranı ise \%10,6'dır. "2017 SBDÖP program kitapçığı genel olarak sade ve işlevsel hazırlanmış olup öğretmenlere kullanım kolaylığı sağlamaktadır. "şeklindeki önermeye "katılıyorum" $(\% 42,4)$ ve "tamamen katılıyorum" (\%28,2) yanıtını verenlerin toplamı \% 70,6 olup bu kategorideki en düşük orandır. Bu önermeye "katılmıyorum $(\% 10,6)$, "kesinlikle katılmıyorum" (\%5,9) ve "kararsızım" $(\% 12,9)$ yanıtını verenlerin oranı bu kategorideki en yüksek oranlardır.

\subsection{Sosyal Bilgiler Öğretmenlerine Göre 2017 SBDÖP’nın Olumlu ve Güçlü Yönleri}

Nitel araştırma modeline göre yarı yapılandırılmış görüşme formu ile gerçekleştirilen araştırmanın bu bölümünde araştırmaya katılan sosyal bilgiler öğretmenlerinin 2017 SBDÖP’nın olumlu ve güçlü yönleri, programın eksik ve zayıf yönleri ile programa ilişkin görüş ve önerileri ortaya konulmaya çalışılmıştır. Araştırmaya katılan sosyal bilgiler öğretmenlerinin 2017 SBDÖP'nın olumlu ve güçlü yönleri olarak ifade ettikleri özelliklerden en yüksek frekansa sahip olan beş yanıt aşağıda tablo hâlinde (Tablo 13) gösterilmiştir.

Tablo 13. Sosyal Bilgiler Öğretmenlerine Göre 2017 SBDÖP’nın Olumlu ve Güçlü Yönleri

\begin{tabular}{clc}
\hline Sıra No & Öğretmenlerin İfadelerine Göre 2017 SBDÖP’nın olumlu ve güçlü yönleri & Frekans \\
\hline $\mathbf{1}$ & Programda kazanımların azaltılmış olması etkinliklere daha fazla zaman ayrılmasına imkân yarattı & 16 \\
$\mathbf{2}$ & Günlük hayat ile konular arasındaki bağlantının iyi/ yeterli düzeyde kurulmuş olması & 9 \\
$\mathbf{3}$ & Kazanımların açık, anlaşılır ve net olması & 8 \\
$\mathbf{4}$ & Programın önceki programa oranla biraz daha basitleştirilmiş ve sadeleştirilmiş olması & 8 \\
$\mathbf{5}$ & Programda toplumumuzun geçmişi ve millî ve manevi değerlere önem verilmiş olması & 8 \\
\hline
\end{tabular}

Tablo 13’te de görüldüğü gibi Araştırmaya katılan sosyal bilgiler öğretmenleri 2017 SBDÖP’nın olumlu ve güçlü yönlerini kazanımların azaltılmıs olması, günlük hayat ile konular arasındaki bağlantının iyi/ yeterli düzeyde kurulmuş olması, kazanımların açık, anlaşılır ve net olması, programın önceki programa oranla biraz daha basitleştirilmiş ve sadeleştirilmiş olması, toplumumuzun geçmişi ve millî ve manevi değerlere önem verilmiş olması şeklinde sıralamışlardır. 


\subsection{Sosyal Bilgiler Öğretmenlerine Göre 2017 SBDÖP’nın Eksik ve Zayıf Yönleri}

Araştırmaya katılan sosyal bilgiler öğretmenlerinin 2017 SBDÖP'nın eksik ve zayıf yönlerine ilişkin yanıtlarından en fazla tekrar ettikleri beş husus aşağıda tablo hâlinde (Tablo 14) gösterilmiştir.

Tablo 14. Sosyal Bilgiler Öğretmenlerine Göre 2017 SBDÖP’nın Eksik ve Zayıf Yönleri

\begin{tabular}{|c|c|c|}
\hline Sira No & Öğretmenlerin İfadelerine Göre 2017 SBDÖP’nın Eksik ve Zayıf yönleri & Frekans \\
\hline 1 & Programda kazanımlar için öngörülen sürelerin yetersiz olmas1 & 13 \\
\hline 2 & $\begin{array}{l}\text { Programda üniteler ve konular arasında bağın yeterince kurulmamıs olması ve konular arasında } \\
\text { kopukluk olması }\end{array}$ & 6 \\
\hline 3 & Programda kazanım sayıları azaltılmakla birlikte hâlâ çok yoğun olması & 6 \\
\hline 4 & $\begin{array}{l}\text { 5. sınıf konularına dâhil edilen Anadolu ve Mezopotamya uygarlıkları konularının soyut olduğundan } \\
\text { öğrencilerin anlama seviyelerine uygun olmaması }\end{array}$ & 6 \\
\hline 5 & Atatürkçülük ile ilgili kazanımların azaltılmıs olması & 5 \\
\hline
\end{tabular}

Tablo 14'te de görüldüğü gibi araştırmaya katılan sosyal bilgiler öğretmenleri 2017 SBDÖP'nın eksik ve zayıf yönlerini programda kazanımlar için öngörülen sürelerin yetersiz olması, üniteler ve konular arasında bağın yeterince kurulmamış olması ve konular arasında kopukluk olması, kazanım bakımından hâlâ çok yoğun olması, 5. sınıf konularına dâhil edilen Anadolu ve Mezopotamya uygarlıkları konularının soyut olduğundan öğrencilerin anlama seviyelerine uygun olmaması, Atatürkçülük ile ilgili kazanımların azaltılmış olması, bazı konu ve kazanımların öğrenci seviyelerine kıyasla çok karmaşık olması, etkinlik örneklerine yer verilmemesi, 5., 6. ve 7. sınıf konuları arasında tekrarların (binişiklik) olması, kavram öğretimi ve ilişkilendirmelere yer verilmemiş olması şeklinde sıralamışlardır.

\subsection{Sosyal Bilgiler Öğretmenlerinin 2017 SBDÖP’da Gerçekleştirilmesini İstedikleri Değişiklikler}

Araştırmaya katılan sosyal bilgileri öğretmenlerinin 2017 SBDÖP'da hangi değişikliklerin gerçekleştirilmesini istersiniz? sorusuna verdikleri yanıtlar içerisinde en yüksek frekansa sahip olanlar aşağıda tablo hâlinde (Tablo 15) gösterilmiştir.

Tablo 15. Sosyal Bilgiler Öğretmenlerinin 2017 SBDÖP’da Gerçekleştirilmesini İstedikleri Değişiklikler

\begin{tabular}{clc}
\hline Sıra No & Gerçekleştirilmesi İstenen Değişiklikler & Frekans \\
\hline $\mathbf{1}$ & Sosyal Bilgiler dersine ayrılan haftalık ders saati miktarları artırılmalıdır & 15 \\
$\mathbf{2}$ & Kültür ve Miras ünitesine (tarih konularına) ayrılan yer artırılmalıdır. & 7 \\
$\mathbf{3}$ & Ögretim programında etkinlik örneklerine yer verilmelidir. & 6 \\
$\mathbf{4}$ & Kazanım sayıları azaltılmalıdır & 5 \\
$\mathbf{5}$ & Anadolu Uygarlıkları ve harita ve ölçeklerle ilgili konular 6. sınıf konuları içerisine aktarılması & 5 \\
$\mathbf{6}$ & Atatürkçülük ile ilgili kazanım sayıları artırılmalıdır. & 5 \\
\hline
\end{tabular}

Yukarıdaki tabloda da (Tablo 15) görüldüğ̈ gibi araştırmaya katılan sosyal bilgiler öğretmenlerinin 2017 SBDÖP'da gerçekleştirilmesi istedikleri değişikliklerden en yüksek frekansa sahip olanlar Sosyal Bilgiler dersine ayrılan haftalık ders saati miktarının artırılması, Kültür ve Miras ünitesine (tarih konularına) ayrılan yerin artırılması, programda etkinlik örneklerine yer verilmesi, kazanım sayılarının azaltılması, Anadolu Uygarlıkları ve harita ve ölçeklerle ilgili konuların 6. sınıf konuları içerisine aktarılması, Atatürkçülük ile ilgili kazanım sayılarının artırılması şeklinde siralanmaktadır.

\section{Tartışma, Sonuç ve Öneriler}

Araştırmanın programın vizyonu, perspektifi, yaklaşımı ve genel amaçları boyutuna iliş̧kin sonuçları sosyal bilgiler öğretmenlerinin genel olarak 2017 SBDÖP'nın vizyonu, perspektifi ve genel yaklaşımının açık ve net olduğu, bireyin bilişsel, duyuşsal ve devinişsel yönden bir bütün olarak gelişimini sağlayacak şekilde hazırlandığı, bilgi-beceri-değer dengesi ile yerellik-ulusallık- 
evrensellik dengesinin yeterli düzeyde kurulduğu, yapılandırmacı yaklaşımın temel ilkeleriyle uyumlu olduğu, öğrenci merkezli bir eğitime yönelttiği, programda yer alan derslerin genel amaçlarının Türk millî eğitiminin genel ve özel amaçlarıyla uyumlu olduğu, genel amaçların çağın genel yönelimlerine uygun olarak belirlendiği ve açık ve anlaşılır olarak ifade edildiği, dersin genel amaçlarına mevcut programla ulaşılabileceği, programın uygulanmasında dikkat edilecek hususlar başlığı altındaki açıklamaların yeterli olduğu ve programın esnek olup, öğretmene şartlara göre uyarlama imkânı sunduğu düşüncesinde olduklarını ortaya koymaktadır. Alan yazın incelendiğinde Taş ve Kıroğlu'nun (2018) araştırmalarının, araştırmanın bu boyutunu destekler nitelikte olduğu anlaşılmaktadır. İnce ve Yavuz (2018) ile Dursun'un (2018) araştırma sonuçları programın yapılandırmacılığa uygun olduğuna yönelik sonuçlarını desteklerken, Demirci (2019) programın öğrenci merkezliliği göz ardı ettĭgi, Pekuslu (2019) ise programın öğrencilerin bilişsel ve duyuşsal seviyelerine uygun olmadığ1 ve öğrenci merkezli bir eğitime olanak tanımadığı şeklinde ulaştıkları sonuçlar araştırmamızın sonuçlarıyla çelişmektedir.

Araştırmanın programın beceriler boyutuna ilişkin sonuçları öğretmenlerin genel olarak program kitapçı̆̆ında beceriler ile ilgili yer verilen teorik bilgi ve açıklamalar ile programda kazandırılması öngörülen becerileri sayıca yeterli bulduklarını; ayrıca programın genel yapısının öngörülen becerileri öğrencilere kazandırabilecek bir yapıda olduğunu ve 2017 SBDÖP'nı 2005 SBDÖP'nın daha ilerisinde olduğunu düşündüklerini ortaya koymaktadır. Bunun yanında araştırmaya katılan öğretmenlerin yarısından daha az bir kısmı $(\% 49,4)$ ise programın üst düzey düşünme becerilerini kazandırmaya uygun olduğunu düşünmektedirler. Alan yazın incelendiğinde İnce ve Yavuz (2018) ile Dursun'un (2019) araştırmalarında programda yer verilen becerilerin sayıca yeterli ve uygun olduğu sonucuna ulaş1lırken, Demirci (2019) programın yer verilen becerileri kazandırabilecek yapıda olmadığını ortaya koymuştur. Çakmak vd., (2018) ile Büyükalan Filiz ve Baysal (2019) çalışmalarında programın üst bilişsel bilgi boyutunun yetersiz olduğu sonucuna ulaşmışlardır ki bu sonuç araştırmamızın sonuçlarıyla örtüşmektedir.

Araştırmanın programın değer eğitimi boyutuyla ilgili sonuçları, öğretmenlerin programda yer alan değer eğitimiyle ilgili kuramsal bilgi ve açıklamaların yeterli olduğu, programın öngörülen değerleri öğrencilere kazandırmaya imkân verecek yapıda olduğu, programda yer verilen değerlerin sayıc yeterli olduğu ve programın bu boyutunun 2005 SBDÖP'ndan daha ileri durumda olduğu düşüncesini taşıdıklarını ortaya koymaktadır. Araştırmanın programın kavram eğitimi boyutuna ilişkin sonuçları sosyal bilgiler öğretmenlerinin önemli oranda program kitapçı̆̆ında kavram öğretimi ile ilgili kuramsal bilgiler ile sınıflar düzeyinde öğretilmesi gereken kavram listelerine yer verilmesi ve kazanım tablosunda ünite-kazanım-kavram ilişkisinin kurulması gerektiğini düşündüklerini ortaya koymaktadır. Araştırmaya katılan öğretmenlerin \%50,6'sı programı kavram öğretimi açısından yeterli görürken, \%72,9'u programı bu boyutuyla 2005 programından daha ileri ve işlevsel bulmaktadır. Alanyazında konuyla ilgili Demirci (2019) tarafından gerçekleştirilen araştırmada da öğretmenlerin öğretim programında kazandırılması hedeflenen kavramların net bir şekilde belirtilmemiş olmasını olumsuz bir durum olarak gördükleri sonucuna ulaşılmıştır.

Araştırmanın 2017 SBDÖP’nın ölçme ve değerlendirme boyutuna ilişkin sonuçları sosyal bilgiler öğretmenlerinin önemli bir bölümünün öğretim programında ölçme ve değerlendirme yöntem ve teknikleri ile ilgili bilgiler ile derslerde kullanılabilecek ölçme ve değerlendirme önerilerine yer verilmesi gerektiği düşüncesinde olduklarını ortaya koymaktadır. Öğretmenlerin \%77,6’s1 programda ölçme ve değerlendirme ile ilgili yer verilen açıklama ve temel kuramsal bilgileri yeterli görürken, \%68,3’ü de 2017 programını ölçme ve değerlendirme boyutuyla 2005 programından daha işlevsel ve ileri bulmaktadırlar. Alanyazın incelendiğinde Taş ve Kıroğlu (2018), Demirci (2019) ve Pekuslu (2019) araştırmalarında öğretmenlerin programın ölçüt, yöntem ve tekniklerinin açık, anlaşılır ve uygulanabilir buldukları sonucuna ulaşmışlardır. Taş ve Kıroğlu (2018), ölçme ve değerlendirme ölçütlerinin program hedefleriyle uyumlu olmadığı, İnce ve Yavuz 
(2018) ise programın standart bir değerlendirme kriteri sunmadığı sonucuna ulaşmıştır. Bu durum da araştırma sonuçlarını desteklemektedir.

Araştırmaya katılan sosyal bilgiler öğretmenleri 2017 SBDÖP'nın öğrenme alanlarının bireyin içinde yaşadığı sosyal hayatın her alanını yeterince kapsadığı, öğrenme alanlarının dersin amaçlarını gerçekleştirmeye imkân verecek şekilde belirlendiği ve 2017 SBDÖP'nın öğrenme alanları boyutuyla 2005 programından daha iyi, işlevsel ve ileri durumda olduğunu düşünmektedirler. Öğretmenlerin programın kazanım boyutuna ilişkin düşünceleri de aynı doğrultudadır. Nitekim araştırma sonuçları katılımcıların programda yer alan kazanımların öğrencilerin bilişsel, duyuşsal ve psikomotor gelişim düzeylerine uygun ve gerçek hayata uyarlanabilir nitelikte olduğu, kazanımların gerek sayı gerekse kapsam bakımından yeterli ve öğrencilerin ilgisini çekecek nitelikte olduğunu düşündüklerini ortaya koymaktadır. Öğretmenlerin önemli bir bölümü programdaki kazanım sayısının azaltılmasını doğru ve yerinde bir uygulama olarak görürken, yarısından daha az bir bölümü kazanımlar için belirlenen süreleri yeterli görmektedirler. Araştırmaya katılan öğretmenlerin kazanımların Atatürkçülük ile ilişkilendirilme düzeyini ve Atatürkçülük ile ilgili kazanımların sayı ve kapsamını kısmen yeterli görmektedirler. İnce ve Yavuz (2018) ile Demirci (2019) tarafından gerçekleştirilen araştırmaların sonuçları araştırmanın öğrenme alanları ile ilgili sonuçlarını destekler niteliktedir.

2017 SBDÖP'nın en belirgin özelliklerinden birisi programda yer alan kazanım sayısının önceki programa oranla önemli ölçüde azaltılmış olmasıdır. Nitekim 2005 programında toplam kazanım sayıs1 175 iken 2017 programında 134'e; 2018 program güncellenmesinde ise 131'e düşürülmüştür (Turan, 2018a; Turan, 2018b). Ancak kazanım sayısındaki bu nicel azalmanın programın kapsam boyutunu olumsuz etkilemediği ve kapsamında kayda değer bir daralmaya yol açmadığ da genel olarak kabul görmektedir (Çoban ve Akşit, 2008; Turan, 2018a). Taş ve Kıroğlu (2018), Dursun (2019), Pekuslu (2019) ve Can (2019) araştırmalarında öğretmenlerin programın kazanımlar boyutuna ilişkin yaklaşımlarının olumlu olduğu sonucuna ulaşmış olup, genel olarak araştırmanın ilgili boyutuna ilişkin sonuçlarıyla paralellik arz etmektedir. Demir ve Hacat (2018) Tarih ve Coğrafya dışındaki konu alanlarıyla ilgili kazanım sayılarının artırılmasını önerirken, Çakmak vd., (2018) ile Büyükalan Filiz ve Baysal (2019) üst düzey bilişsel kazanımlara ilişkin kazanımların yetersiz olduğu sonucuna ulaşmışlardır ki bu da araştırmamızda ortaya çıkan sonuçla örtüşmektedir.

Araştırma sonuçları sosyal bilgiler öğretmenlerinin yüksek sayılabilecek oranlarda sosyal bilgiler dersi öğretim programlarında ders içi, dersler arası ve ara disiplinlerle ilişskilendirmelere yer verilmesi gerektiğini düşündüklerini ortaya koymaktadır. Alanyazın incelendiğinde İnce ve Yavuz (2018), Demirci (2019), Turan (2018a) ve Can (2019) ve Tonga (2019) tarafindan gerçekleştirilen araştırmalarda da Atatürkçülük ile ilgili kazanımlara daha fazla yer verilmesi gerektiği sonucuna ulaşıldığı anlaşılmaktadır. Araştırma sonuçları sosyal bilgiler öğretmenlerinin öğretim programının kazanım tablosunda öğrenme alanları ve kazanımlarla bağlantılı olarak derslerde kullanılabilecek materyal, sınıf-okul içi etkinlik, okul dışı etkinlik-inceleme gezisi ile derste kullanılabilecek yöntem ve teknik önerilerine yer verilmesi gerektiğini düşündüklerini ortaya koymaktadır. Bunun yanı sıra araştırmaya katılan öğretmenlerin önemli bir bölümünün (\%70,6) 2017 sosyal bilgiler dersi öğretim programı kitapçığının genel olarak sade ve işlevsel hazırlanmış olduğunu ve bu yönüyle öğretmenlere kullanım kolaylığı sağladığını düşündükleri anlaşılmaktadır. İnce ve Yavuz (2018) ve Demirci (2019) araştırmalarında programda etkinliklere yer verilmesinin önemini vurgulamışlardır.

Araştırmanın nitel bölümünde araştırmaya katılan öğretmenler 2017 SBDÖP’nın en olumlu ve güçlü yönlerini "kazanımların azaltılmıss olması", "gündelik hayat ile konular arasındaki bağlantının iyi ve yeterli düzeyde kurulmuş olması", "kazanımların açık, anlaşılır ve net bir şekilde ifade edilmiş olması", "programın 2005 programına oranla biraz daha basitleştirilmiş ve sadeleştirilmiş olması" ve "toplumumuzun geçmişi ve millî-manevi değerleri ön planda tutması" 
olarak; programın zayıf ve eksik yönlerini ise "kazanımlar için öngörülen sürelerin yetersiz olması", "öğrenme alanları ve konular arasında kopukluk olması", "kazanım sayısının hâlâ çok fazla olması", "5. sınıf konularına dâhil edilen Anadolu ve Mezopotamya uygarlıkları konularının soyut olup, öğrencilerin anlama seviyelerinin üstünde olması" ve "Atatürkçülük ile ilgili kazanımların azaltılmış olması" şeklinde sırlamışlardır. Araştırmaya katılan sosyal bilgiler öğretmenleri sosyal bilgiler dersi öğretim programında gerçekleştirilmesini istedikleri değişiklikleri ise "sosyal bilgiler dersine ayrılan haftalık ders saati miktarının artırılması", "Kültür ve Miras öğrenme alanına, tarih konularına daha fazla yer ayrılması", "öğretim programında etkinlik örneklerine yer verilmesi”, "kazanım sayılarının azaltılması", "Atatürkçülük ile ilgili kazanım sayılarının artırılması" ve "programda kavram öğretimi ile ilgili hususlara yer verilmesi” olarak sıralamışlardır.

Can'ın (2019) araştırmasında da sosyal bilgiler öğretmenleri programda kazanımların azaltılarak sadeleştirilmesini programın güçlü bir yönü olarak değerlendirmişler, ayrıca programın 2005 SBDÖP'na oranla öğrenci seviyesine daha uygun olduğunu ifade etmişlerdir.

Araştırmaya katılan öğretmenlerin sosyal bilgiler dersine ayrılan haftalık ders saati miktarını yetersiz bulmaları ve artıılmasını önermeleri alanyazındaki birçok çalışmanın sonuçlaraıyla da uyumluluk sergilemektedir. Nitekim Taş ve Kıroğlu (2018), İnce ve Yavuz (2018), Can (2019) ve Dursun (2019) da araştırmalarında sosyal bilgiler dersinin haftalık ders saati miktarlarının artırılması gerektiği sonucuna ulaşmışlardır.

Araştırma sonuçları genel olarak değerlendirildiğinde araştırmaya katılan sosyal bilgiler öğretmenlerinin 2017 SBDÖP'nı genel olarak (\%50-80 arasında değişen oranlarda) olumlu bulduklarını; sadece programın üst düzey düşünme becerilerini kazandırmaya pek uygun bulmadıklarını ortaya koymaktadır. Bir dersi okutan öğretmenlerin o dersin öğretim programını tanıma, onaylama ve benimseme düzeyinin dersin amacına uygun ve başarılı bir şekilde işlenmesi üzerindeki doğrudan etkisi hesaba katıldığında, esasen programın farklı boyutlarının yukarıda bahsedilen oranlarda olumlu görülmesinin yeterli görülmemesi gerektiği de açıktır. Dolayısıyla programın öğretmenler tarafindan yeterli görülme ve benimsenme oranlarını olabildiğince yükseltilmesi hedeflenmelidir. Bunun için gerek programın uygulanma sürecinin izlenerek elde edilen sonuçlar, gerekse konuyla ilgili gerçekleştirilmiş araştırma sonuçlarından yararlanmak suretiyle öğretmenlerin programda gerçekleştirilmesini istedikleri değişiklik önerilerini de dikkate alarak programın güncellenmesinin yararlı olacağı düşünülmektedir. Ayrıca gerek bu araştırmada verilen bazı çelişkili yanıtlar, gerekse alanyazındaki başka çalışmalar sosyal bilgiler öğretmenlerinin önemli bir kısmının program hakkında yeterli bilgiye sahip olmadığını ortaya koymaktadır. Aynı şekilde haftalık ders saatlerinin artırılması önerisi haklı gerekçelere dayansa da bu ihtiyacın en aza indirilmesi ancak öğretmenlerin sınıf yönetimi, sınıf içi uygulama vb. konulardaki yeterlilik düzeylerini artırmayla mümkün olabilir. Bu nedenle bir yandan programın eksiklikleri giderilmeye çalışılırken, öte yandan etkili sürekli hizmet içi eğitim faaliyetleriyle sosyal bilgiler öğretmenlerinin öğretim programının tanıma ve uygulama becerilerinin geliştirilmesine yoğunlaşılmasının yararlı olacağ1 düşünülmektedir.

\section{Kaynakça}

BEKTAŞ, Özlem (2019). “Sosyal Bilimler ve Sosyal Bilgiler”, ed. R. Turan ve T. Yıldırım, Sosyal Bilgilerin Temelleri, ss. 1-34, Ankara: Anı Yayıncilık.

BÜYÜKALAN Fİİ, Sevil ve Sefa Burak BAYSAL (2019). "Sosyal Bilgiler Dersi Öğretim Programı Kazanımlarının Revize Edilmiş Bloom Taksonomisine Göre Analizi”, İnönü Üniversitesi Eg̈itim Fakültesi Dergisi, 20(1): 234-253.

CAN, Büşra (2019). 2005 ve 2018 Sosyal Bilgiler Dersi Öğretim Programlarının İncelenmesi, (Yayımlanmamış Yüksek Lisans Tezi), Balıkesir Üniversitesi Sosyal Bilimler Enstitüsü, Balıkesir. 
ÇAKMAK, Zafer, KAÇAR, Turan ve Birol BULUT (2018). "Beşinci Sınıf Sosyal Bilgiler Öğretim Programı Kazanımlarının Yenilenmiş Bloom Taksonomi Boyutlarına Göre Analizi”, Jass Studies-The Journal of Academic Social Science Studies, 72: 145-156.

ÇOBAN, Okan ve İbrahim AKȘİT (2018). “2005 ve 2017 Sosyal Bilgiler Öğretim Programlarının Öğrenme Alanı, Kazanım, Kavram, Değer ve Beceri Boyutları Açısından Karşılaştırılması", Tarih Kültür ve Sanat Arastırmaları Dergisi, 7 (1): 479-505.

DEMIR, Fatıma Betül ve Sibel OĞUZ HAÇAT (2018). "Sosyal Bilim Disiplinlerine Göre 2005 ve 2018 Sosyal Bilgiler Dersi Öğretim Programındaki Kazanımların Değerlendirilmesi”, Uluslararası Sosyal Bilgilerde Yeni Yaklaşımlar Dergisi, 2(2): 27-56.

DEMIRCİ, Meltem (2019). 2017 Sosyal Bilgiler Öğretim Programının Sosyal Bilgiler ve Sınıf Öğretmenlerinin Görüşlerine göre değerlendirilmesi (Kars İli Örneği), (Yayımlanmamış Yüksek Lisans Tezi), Kafkas Üniversitesi Sosyal Bilimler Enstitüsü, Kars.

DEMIREL, Özcan (2005). Eğitimde Program Gelistirme, Ankara: Pegem Yayınevi.

DOĞANAY, Ahmet (2002). "Sosyal Bilgiler öğretimi”, ed. C. Öztürk ve D. Dilek, Hayat Bilgisi ve Sosyal Bilgiler Öğretimi, ss. 15-46, Ankara: Pegem A Yayıncılık.

DURSUN, Ayşe (2019). 2018 Sosyal Bilgiler Öğretim Programına İlişkin Öğretmen ve Akademisyenlerin Görüș ve Değerlendirmeleri, (Yayımlanmamıș Yüksek Lisans Tezi), Marmara Üniversitesi Eğitim Bilimleri Enstitüsü, İstanbul.

ERSOY, Arife Figen ve Erdoğan KAYA (2009). "Sosyal Bilgiler Dersi Öğretim Programının (2004) Uygulama Sürecine İlişkin Öğrenci Görüşleri”, Kastamonu Eğitim Dergisi, 17 (1): $71-86$

İNCE, Murat ve Özlem KUUK YAVUZ (2018). "5. Sınıf Sosyal Bilgiler Dersi Öğretim Programının Eisner Eğitsel Eleştiri Modeline göre Değerlendirilmesi”, Akdeniz Eğitim Araștırmalar Dergisi, 12(26), 407-426.

KARASAR, Niyazi (1998). Bilimsel Araştırma Yöntemi, Ankara: Nobel Yayın Dağıtım.

LEECH, Nancy L. ve Anthony J. ONWUEGBUZIE (2009). “A Typology of Mixed Methods Research Designs", Qual Quant, 43: 265-275.

MEB (2017a). Sosyal Bilgiler Dersi Ögrretim Programı (Ilkokul ve Ortaokul 4, 5, 6 ve 7. Simflar), Ankara: MEB Yayınları (PDF formatında) Tarihi:

MEB (2017b). “Müfredatta Yenileme ve Değişiklik Çalışmalarımız Üzerine...” Erişim (https://ttkb.meb.gov.tr/meb_iys_dosyalar/2017_07/18160003_basin_aciklamasi-program.pdf).

MEB (2018). "Sosyal Bilgiler Dersi Öğretim Programı (Illkokul ve Ortaokul 4, 5, 6 ve 7. Sinıflar)", Erişim tarihi: 01.9.2019, (http://mufredat.meb.gov.tr/Dosyalar/201812103847686SOSYAL $\% 20 \mathrm{~B} \% \mathrm{C} 4 \% \mathrm{~B} 0 \mathrm{LG} \% \mathrm{C} 4 \% \mathrm{~B} 0 \mathrm{LER} \% 20 \% \mathrm{C} 3 \% 96 \% \mathrm{C} 4 \% 9 \mathrm{ERET} \% \mathrm{C} 4 \% \mathrm{~B} 0 \mathrm{M} \% 20 \mathrm{PROG}$ RAMI\%20.pdf).

NEUMAN, W. Lawrence (2012). Toplumsal Arasstirma Yöntemleri: Nicel ve Nitel Yaklassımlar III., İstanbul: Yayın Odas1 Yayınları.

ÖZTÜRK, Cemil (2012). Sosyal Bilgiler: “Toplumsal Yaşama Disiplinler Arası Bir Yaklaşım”, ed. C. Öztürk, Sosyal Bilgiler Öğretimi, Demokratik Yurttaşlı Eğitimi, ss. 1-31, Ankara: Anı Yayıncllik. 
TURAN, Refik (2020). “2017 Sosyal Bilgiler Dersi Öğretim Programına İlişkin Öğretmen Görüşleri (Aksaray İli Örneği)", Mavi Atlas, 8(2): 256-277

PEKUSLU, M. Niyazi (2019). 5. Sınıf Sosyal Bilgiler Dersi Öğretim Programına İlişkin Sosyal Bilgiler Öğretmenlerinin Görüşleri, (Yayımlanmamış Yüksek Lisans Tezi), Pamukkale Üniversitesi Eğitim Bilimleri Enstitüsü, Denizli.

SÖNMEZ, Veysel (2010). Sosyal Bilgiler Ögrretimi ve Öğretmen Kılavuðu, Ankara: Anı Yayınc1lı.

TAŞ, Halil ve Kasım KIROĞLU (2018). "2017 İlkokul Sosyal Bilgiler Dersi Öğretim Programı'nın Öğretmen Görüşlerine Göre Değerlendirilmesi”, Elementary Education Online, 17(2): 697-716.

TD (2017) “Sosyal Bilgiler Dersi Öğretim Programı”, MEB Tebliğler Dergisi, 2718: 1613.

TONGA, Deniz (2019). “2005 ve 2017 Sosyal Bilgiler Öğretim Programı: Benzerlikler ve Farkll11klar”, Diyalektolog Ulusal Sosyal Bilimler Dergisi, 22: 83-100.

TURAN, Refik (2016). "Millî Tarihten Sosyal Bilgilere Türkiye'de İlköğretim Düzeyinde Tarih Öğretimi”, The Journal of Academic Social Science Studies (JASSS), 49: 257-278.

TURAN, Refik (2018a). "2017 İlkokul ve Ortaokul Sosyal Bilgiler Dersi Öğretim Programı Üzerine Genel Bir Değerlendirme”, Diyalektolog Ulusal Sosyal Bilimler Dergisi, 19: 295-328.

TURAN, Refik (2018b ). "2017 İlköğretim Sosyal Bilgiler Öğretim Programında 2018 Yllında Gerçekleştirilen Güncelleme Üzerine Bir Değerlendirme" Uluslararası Akşsemseddin İnsan, Toplum ve Spor Bilimleri Sempozyumu (12-16 Eylül 2018) Bildiriler Kitabı, ss. 620-629, Çorum.

YILDIRIM, Ali ve Hasan ŞIMŞEK (2003). Sosyal Bilimlerde Nitel Araștırma Yöntemleri, Ankara: Seçkin Yayınevi. 
TURAN, Refik (2020). “2017 Sosyal Bilgiler Dersi Öğretim Programına İlişkin Öğretmen Görüşleri (Aksaray İli Örneği)", Mavi Atlas, 8(2): 256-277

Ek:

\section{Etik Kurul Onayı Belgesi} Karar 2019/03-45: Yürütücülüğünü Mustafa ÇAPRAZ' nn yaptığı “Sosyal Bilgiler Öğgretiminde Edebi Metin Olarak
Şiirin Kullanımı" başlklı araştırma ile ilgili 2019/03-45 protokol numaralı başvuru kurulumuz tarafindan incelenmiş,
Üniversitemiz İnsan Araştırmaları Etik Kurul Yönergesi’nde belirtilen etik ilkelere uygun olduğuna, toplantıya katılan
üyelerin oy birliği ile karar verilmiştir.

Karar 2019/03-46: Yürüttücüllüğünü Doç. Dr. Refik TURAN’ın yaptığ1 “2017 İlkokul ve Ortaokul Sosyal Bilgiler Dersi Öğretim Programına İlişkin Öğretmen Görüşleri (Aksaray İli Örneği)” başlıklı araştırma ile ilgili 2019/03Yönergesi'nde belirtilen etik ilkelere uyguz tarafindan incelenmiş, Üniversitemiz İnsan Araştırmaları Etik Kurul Yönergesi'nde belirtilen etik ilkelere uygun olduğuna, toplantıya katılan üyelerin oy birliği ile karar verilmiștir.

Karar 2019/03-47: Yürütücülüğünü İhsan KUZUCU'nun yaptı̆ğ “Ameliyat Öncesi Anksiyetenin Uyanma Sonrası Acil Ajitasyona Etkisi" başlıklı araşıırma ile ilgili 2019/03-47 protokol numaralı başvuru kurulumuz tarafindan incelenmiş, Üniversitemiz İnsan Araştırmaları Etik Kurul Yönergesi'nde belirtilen etik ilkelere uygun olduğuna,
toplantıya katılan üyelerin oy birliği ile karar verilmiştir.

Karar 2019/03-48: Yürütücülüğünü Onur KARACA'nın yaptığı "Yoğun Bakımda İntihar Amaçlı İlaç İçen Hastaların Retrospektif Olarak İncelenmesi” başlıklı araştırma ile ilgili 2019/03-48 protokol numaralı başvuru kurulumuz tarafindan incelenmiș, Üniversitemiz İnsan Araştırmaları Etik Kurul Yönergesi'nde belirtilen etik ilkelere uygun olduğuna, toplantıya katılan üyelerin oy birliği ile karar verilmiştir.

Karar 2019/03-49: Yürütücülüğünü Doç. Dr. Sinem SOMUNOĞLU İKINCCI'nin yaptığı “Hastane Çalışanlarının Bilgi Güvenliği Farkındalıkları Üzerine Bir Araştırma" başlıklı araştırma ile ilgili 2019/03-49 protokol numaralı başvuru kurulumuz tarafindan incelenmiş, Üniversitemiz İnsan Araştırmaları Etik Kurul Yönergesi’nde belirtilen etik ilkelere uygun olduğuna, toplantıya katılan üyelerin oy birliği ile karar verilmiştir.

Karar 2019/03-50: Yürütücülüğünü Așkın YERDEN'in yaptı̆ğ “Sedanter Adolesanlarda Tekrarlı Sprint ve İnterval Antrenmanlarınm Bazı Fiziksel ve Fizyolojik Parametreler ile Öz Yeterliliğe Etkisi” başlıklı araştırma ile ilgili 2019/03-50 protokol numaralı başvuru kurulumuz tarafindan incelenmiş, Üniversitemiz İnsan Araștışmaları Etik Kurul Yönergesi'nde belirtilen etik ilkelere uygun olduğuna, toplantıya katılan üyelerin oy birliği ile karar
verilmiştir. verilmiştir.

Karar 2019/03-51: Yürütücülüğünü Uzm. Dr. Derya IŞIKLAR ÖZBERK' in yaptığı "Birinci Basamakta Koleraktal Kanserlerden Korunma ve Erken Tanıda Sağlık İnançlarının Tarama Testi Yaptırmaya Etkisi, Gaitada Gizli Kan Testi Uygulanabilirliği ve Test Sonuçları” başlıklı araştırma ile ilgili 2019/03-51 protokol numaralı başvuru kurulumuz tarafindan incelenmiş, Üniversitemiz İnsan Araştırmaları Etik Kurul Yönergesi'nde belirtilen etik ilkelere uygun olduğuna, toplantıya katılan üyelerin oy birliği ile karar verilmiștir.

Karar 2019/03-52: Yürütücülüğünü Cemile KÜTMEÇ YILMAZ'ın yaptı̆̆ı "Hastanede Yatan Kronik Obstrüktif Akciğer Hastalığı Olan Bireylerde Dispne Şiddeti ve Konfor Düzeyi Arasındaki İlişkinin Belirlenmesi” bașlıklı araştırma ile ilgili 2019/03-52 protokol numaralı başvuru kurulumuz tarafindan incelenmiş, Üniversitemiz İnsan Araștırmaları Etik Kurul Yönergesi’nde belirtilen etik ilkelere uygun olduğuna, toplantıya katılan üyelerin oy birliği
ile karar verilmiştir.

Karar 2019/03-53: Yürütücülüğünü Efe Numan CAN'ın yaptığı "Olumlu ve Olumsuz Mesaj Stratejileri Bağlamında Siyasi Liderin Seçmen Davranışları Üzerine Etkisi: 31 Mart 2019 Mahalli İdareler Seçimi Örneği” başlıklı araștırma ile ilgili 2019/03-53 protokol numaralı başvuru kurulumuz tarafından incelenmiş, Üniversitemiz İnsan Araștırmaları Etik Kurul Yönergesi'nde belirtilen etik ilkelere uygun olmadığına, toplantıya katılan üyelerin oy birliği ile karar verilmiştir.

Karar 2019/03-54: Yürütücülüğ̈ünü İsmail ÇETINKAYA'nın yaptığı "Düşünce Deneyi Etkinliklerinin 8. Sınıf Öğrencilerinin Basit Makineler Ünitesi Kavramsal Anlamalarına Etkisi” başlıklı araştırma ile ilgili 2019/03-54 protokol numaralı başvuru kurulumuz tarafindan incelenmiş, Üniversitemiz İnsan Araştırmaları Etik Kurul Yönergesi'nde belirtilen etik ilkelere uygun olduğuna, toplantıya katılan üyelerin oy birliği ile karar verilmiştir.

Karar 2019/03-55: Yürütücülüğünü Cemile KÜTMEÇ YILMAZ'ın yaptığı “Kronik Hastalığı Olan Bireylerin Spiritüel Iyi Oluş Düzeyinin Kronik Hastalığa Uyuma Etkisi” bașlıklı araştırma ile ilgili 2019/03-55 protokol numaralı başvuru kurulumuz tarafindan incelenmiş, Üniversitemiz İnsan Araştırmaları Etik Kurul Yönergesi'nde belirtilen etik ilkelere uygun olduğuna, toplantıya katılan üyelerin oy birliği ile karar verilmiştir.

Karar 2019/03-56: Yürütücülüğünü Dr. Öğr. Üyesi Funda KEMERIZ’in yaptığı “Akne Rosacea Hastalarında Psikiyatrik Ölçeklerin ve Uyku Kalite Düzeyinin Değerlendirilmesi” başlıklı araştırma ile ilgili 2019/03-56 protokol numaralı başvuru kurulumuz tarafindan incelenmiş, Üniversitemiz İnsan Araştırmaları Etik Kurul Yönergesi'nde belirtilen etik ilkelere uygun olduğuna, toplantıya katılan üyelerin oy birliği ile karar verilmiş̧tir.

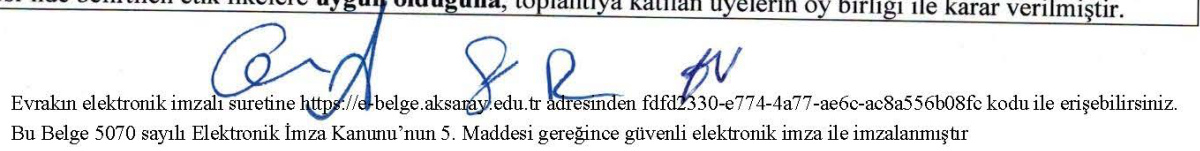

